\title{
A Glimpse into Advances in Archaeological Research in North-Central Uruguay
}

\author{
Hugo G. Nami \\ Laboratory of Geophysics "Daniel A. Valencio", Department of Geological Sciences, CONICET-IGEBA, FCEN, UBA, \\ Ciudad Autónoma de Buenos Aires, Argentina \\ Email: hgnami@fulbrightmail.org
}

How to cite this paper: Nami, H. G. (2020). A Glimpse into Advances in Archaeological Research in North-Central Uruguay. Archaeological Discovery, 8, 147-187. https://doi.org/10.4236/ad.2020.82009

Received: February 15, 2020

Accepted: March 10, 2020

Published: March 13, 2020

Copyright $\odot 2020$ by author(s) and Scientific Research Publishing Inc. This work is licensed under the Creative Commons Attribution International License (CC BY 4.0).

http://creativecommons.org/licenses/by/4.0/

(c) (i) Open Access

\begin{abstract}
The Tacuarembó Department of north-central Uruguay, and especially in the middle portion of the Negro River, has produced a rich and diverse archaeological record, mostly characterized by significant evidence of stone tool remains. The evidence comprises one of the largest collections of artifacts witnessing early human occupation in the region during the terminal Pleistocene about $11,000-10,000$ uncalibrated radiocarbon years ago. As part of a long-term research program aimed at exploring and understanding diverse aspects of the regional archaeological process, mainly focusing on the earliest people who colonized the New World, as well as to deepen and expand knowledge on diverse aspects of the Late Pleistocene and post-Pleistocene stone tool technologies employed by the prehistoric people living in this part of southeastern South America. Systematic research enabled numerous field and laboratory activities to be conducted. To build a chronostratigraphic framework for the regional archaeological process, various dating methods were used. Furthermore, diverse technological analyses on lithic artifacts facilitated recognition of the existence of unreported techniques and reduction strategies employed by the prehistoric inhabitants. By this way this paper summarizes the observations and results obtained during the most recent field and laboratory investigation carried out in Tacuarembó by offering a glimpse into the use of diverse scientific disciplines and approaches that may help to deepen various topics concerning the regional prehistoric past. The archaeological excavations as well as the variety of dating methods used have allowed us to understand the chronology and certain aspects of the site formation process revealing important depositional gaps and hiatuses of several thousand years in the dated sedimentary deposit. The new technological investigations have permitted more detailed knowledge to be collected regarding diverse topics related to the reduction systems existing in the area since the terminal Pleistocene. Indeed, the Paleoindian remains add new finds to the record of
\end{abstract}


the early colonizers living in Tacuarembó during the last millennium of the Pleistocene. Also, the identification of clear turtle-back Levallois-like cores agrees with earlier finds in other locations in southeastern South America and yielded excellent examples of the employment of the flaking strategy by the prehistoric populations living in Tacuarembó. From the experimental lithic technology perspective, modern reproductions of the stone tools afforded an understanding of various aspects of the reduction sequences and technical features of their analogs from the past.

\section{Keywords}

Hunter-Gatherer Archaeology, Paleoindian, Lithic Analysis, Chronology, Late Pleistocene-Holocene, South America

\section{Introduction}

The Uruguayan archaeological record has long been of intellectual interest (e.g. Figueira, 1892; Maruca Sosa, 1957; Cordero, 1960; Taddei, 1969, 1977, 1980, 1985; among many others). Professional research undertaken throughout the years across the country-particularly in north-central Uruguay in the Tacuarembó Department-has revealed a rich and varied archaeological record suggesting differences in subsistence and social organization (e.g. López Mazz et al., 2003-2004; Gianotti, 2005; Iriarte, 2006; Gianotti et al., 2013; among others). In particular, Tacuarembó has produced abundant vestiges characterized by significant evidence of stone tool remains. Besides those left by hunter-gatherers during the Holocene, these include one of the largest collections of artifacts evidencing the presence of early human occupation during the terminal Pleistocene at about 11,000 - 10,000 uncalibrated radiocarbon years ago (hereafter $\sim 11.0-10.0 \mathrm{kya}$ ).

The archaeological activities in Uruguay were initiated as part of a long-term research program aimed at exploring and understanding diverse aspects of the regional archaeological process, mainly focusing on the earliest people who colonized the New World, as well as to deepen and expand knowledge on prehistoric lithic technologies from the Americas. Therefore, this investigation not only seeks to study the remains of the presence of the earliest foragers, but also to enhance information on diverse aspects of the Late Pleistocene and post-Pleistocene stone tool technologies employed by the prehistoric people living in this part of southeastern South America (Nami, 2001a, 2001b, 2007, 2010, 2013; among others). Moreover, a crucial topic to cope with the regional archaeological process is the building of a chronostratigraphic framework through the use of various complementary methods. This paper offers a glimpse into the results of the most recent field and laboratory investigation carried out in Tacuarembó.

\section{Briefs on the Geological and Environmental Setting}

Situated in southeastern South America, Uruguay is located within the Pampa 
biome and is largely characterized by fluvial sediments of the Rio de la Plata Basin, one of the five largest basins in the world (del Castillo Laborde, 2008). Covering a surface area of $15,438 \mathrm{~km}^{2}$, Tacuarembó is the largest of the nineteen territorial departmental divisions of this subtropical temperate country (Figure 1). The climate presents a respective maximum and minimum temperature range of $5^{\circ} \mathrm{C}$ and $41^{\circ} \mathrm{C}$, with an annual average of $18^{\circ} \mathrm{C}$, and annual precipitation varying between 1200 and $1400 \mathrm{~mm}$.

Various geological events have occurred in Tacuarembó, forming different kinds of landscapes. Diverse geological formations manifesting a long geological process (Bossi \& Navarrro, 1998; A.C.R.T., n.d.) are represented by two main Mesozoic formations. The oldest is constituted of sandstones and is named Tacuarembó; the other comprises extended basaltic outcrops and is called Arapey (A.C.R.T., n.d.). Briefly summarizing, the different topographical relief from east to west across the department are as follows. The largest part of the east is a peneplain characterized by hills with soft slopes, where the streams gently flow without very extensive alluvial plains; its northern portion is the area of the "sierra", comprising escarpments with mesas and plains; finally, the west is marked by a basaltic slope of the range Cuchilla de Haedo. This is a low-range system that begins at Cuchilla Negra on the Brazilian border, and ends at the confluence of the Negro River and the Uruguay River, the natural western border with Argentina (da Silva, 1970; A.C.R.T., n.d.; E.G.d.U., 2019). The landscape from the northern and southern portions of the department presents an interesting contrast. In the north, the pastures are sometimes interspersed with either isolated or groups of mesetiform hills, which have wide and flattened tops, and rocky outcrops with bushy vegetation on their slopes. However, the south is characterized by undulating basaltic low hills, mainly covered by stony prairie vegetation (Figure 2).
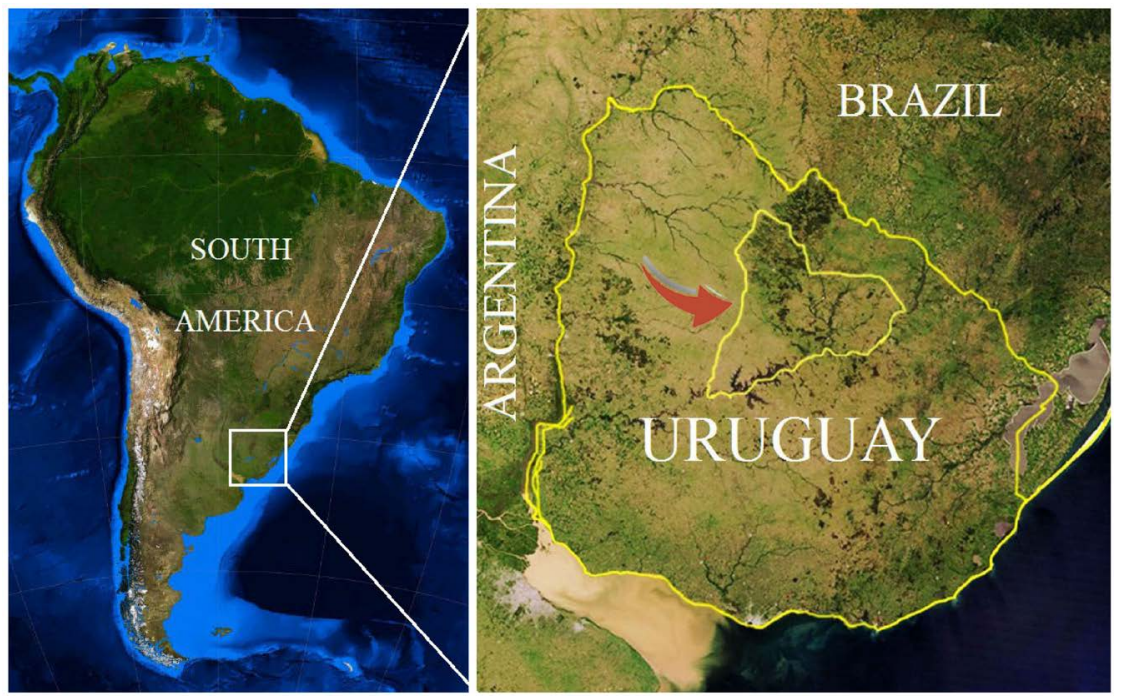

Figure 1. Location maps of the studied area: (a) South America; (b) Tacuarembó Department within Uruguay indicated with an arrow. Modified from NASA maps. 

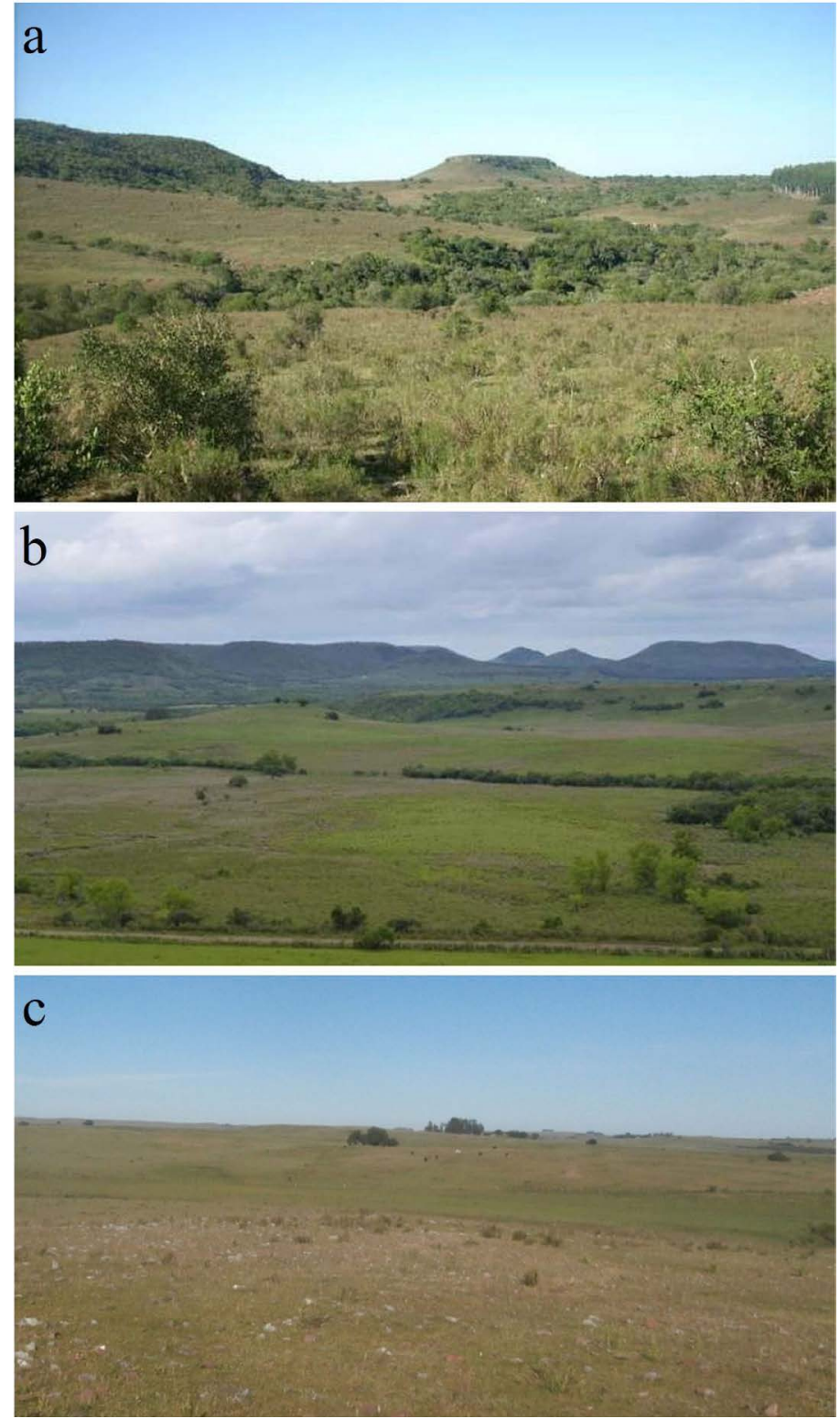

Figure 2. Examples of the varied topographical relief observed at Tacuarembó. (a) Mesetiform hill with a wide and flattened top; (b) Groups of hills observed from the Eden valley; (c) Peneplain mainly covered by stony prairie vegetation. Photographs courtesy: R. Cáceres.

The department is crossed by a large number of watercourses varying in magnitude (Praderi et al., 2006), the main ones being the Negro River and one of its most important tributaries, the Tacuarembó. The latter and its many watercourses, including the significant Caraguatá, Yaguarí, Veras, Cañas and Tres Cruces creeks, pass through the largest part of the department's northern portion. Dividing the south from the north of the country, the Negro River is the most important inner fluvial course in Uruguay. Originating to the north of Bage city about $70 \mathrm{~km}$ from Uruguay's northern border with Brazil, it flows west across the country to the Uruguay River. In Uruguayan territory, its drainage basin size is $70,714 \mathrm{~km}^{2}$, with a total length of $750 \mathrm{~km}$. In its middle basin, the river is 
dammed near Paso de los Toros city to create the Rincón del Bonete dam (also called the Gabriel Terra), which with a surface area of about $1500 \mathrm{~km}^{2}$ represents one of the largest reservoirs in South America. In Tacuarembó Department, the Negro River also has several significant important streams that flow into its channel, including El Malo, Clara, Achar, Cardozo, and the Salsipuedes Grande, as well as its main tributary, the Salsipuedes Chico. One important feature of these fluvial courses is that along their shores is significant vegetation, forming a native riparian forest. Another remarkable characteristic of the main regional rivers such as the Tacuarembó and Negro is that along their courses are patches of extensive dunes of diverse sizes, a great part of them recently being consolidated with widespread eucalyptus forest (Figure 3 and Figure 4).

Especially along the watercourses is alluvium of variable thickness, and that corresponding to the Late Pleistocene and Holocene is of particular archaeological interest. Characterizing the terminal Pleistocene, the former is called the Sopas-Dolores (Panario \& Gutiérrez, 1999) or Dolores Formation (Martinez \& Ubilla, 2004), and is an extensive brown to green sedimentary silt that can be identified throughout Uruguay (e.g. Martinez \& Ubilla, 2004; Ubilla \& Martínez, 2016; Feathers \& Nami, 2018).
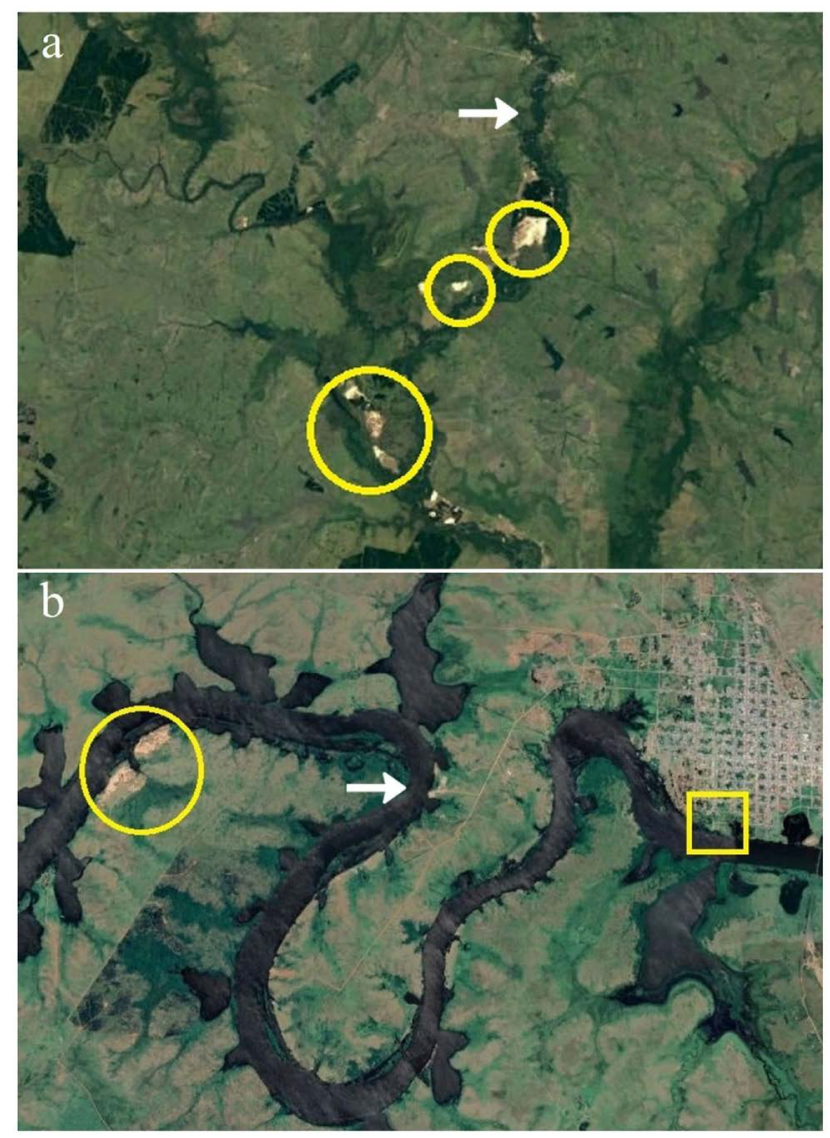

Figure 3. Satellite images of the dunes (marked with a circle) currently observable in the Tacuarembó (a) and Negro River (b) drainage systems, identified with an arrow. The square denotes consolidated dunes by eucalyptus forest. Modified from Google Maps. 


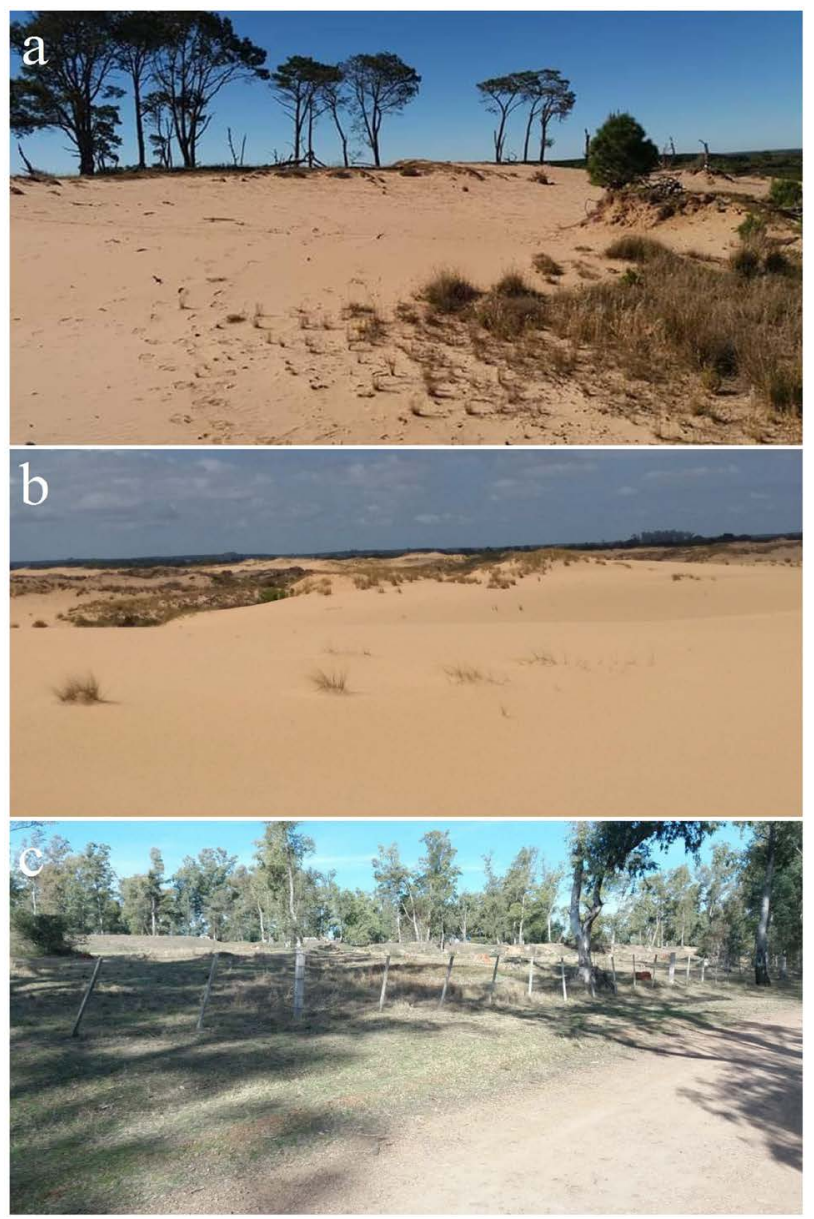

Figure 4. Examples of unconsolidated dunes at Paso de los Novillos and Viuda de Salazar on the Tacuarembó Chico River (a) and (b), and consolidated dunes by eucalyptus forest at Parque de los Curas on the Negro River shore in the city of Paso de los Toros (c). (a) and (b) Photo courtesy of R. Cáceres. Apart from where clearly expressed, all pictures and illustrations are by Hugo G. Nami.

As can be seen in Figure 5, in some localities overlying the Sopas-Dolores (or just directly on the bedrock) are varied recent sedimentological strata, some being composed of pale brown and gray sandy sediments and/or a remarkably black clay stratum, which are probably remnant peats from wetlands that covered much of Uruguay during the Holocene (Iriarte, 2006). The black levels with high organic content suggest a climatic change to humid conditions (Iriarte, 2006), a conclusion supported by pollen (Behling et al., 2002; Iriarte, 2006), diatoms (Moro et al., 2004), and phytoliths (Iriarte, 2006).

Following is a summary of some of the chronological and archaeological issues in relation with the described geological framework.

\section{A Synopsis of Research Advances}

\subsection{General Remarks}

Advancing previous research in the Southern Cone, a long-term archaeological project commenced in Uruguay at the end of the 1990s. Different studies were 


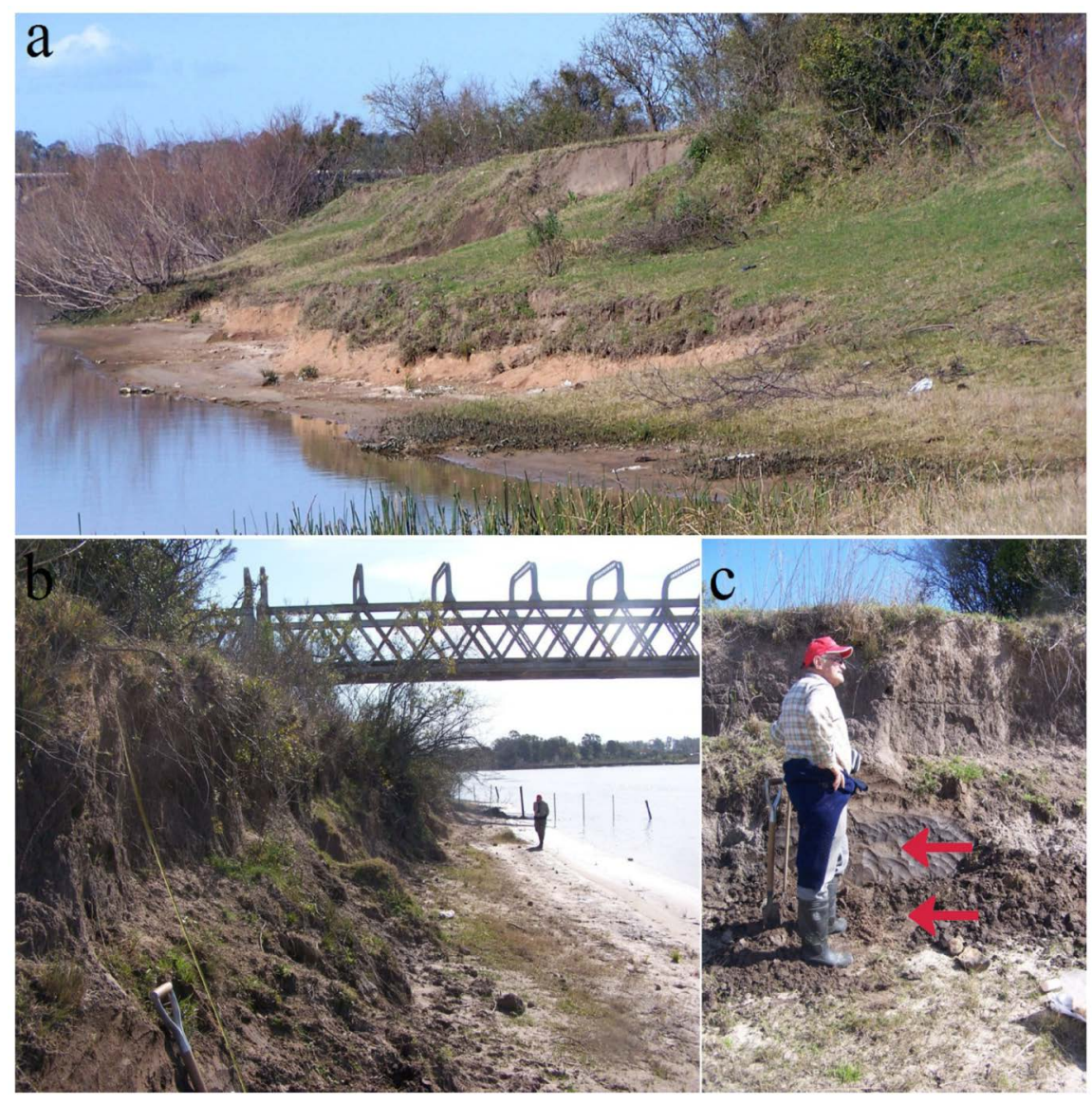

Figure 5. Illustrative examples of terminal Pleistocene/Holocene geological sections on the Negro River's shores. The arrows in (c) indicate the black clay stratum and the Sopas-Dolores Formation.

performed in different places across the country, but mainly in the Tacuarembó Department and principally in the middle Negro River basin (e.g. Femenías et al., 2011; Nami, 2001a, 2001b, 2007, 2013, 2017a; Nami \& Castro, 2010, 2014; Feathers \& Nami, 2018). They involved diverse kinds of fieldwork, including detailed studies on lithic artifacts curated at museums and private collections, as well as laboratory research. Given the lack of careful archaeological diggings in the region, it was crucial to excavate sites containing buried remains, not least because they have been disappearing due to fluvial erosion, and surviving sites on the riverbanks are continuously affected by water level fluctuations. Below is a synopsis of previous research and new data on the most recent results.

\subsection{Archaeological Excavations}

As exemplified in Figure 6, one of the most remarkable aspects of Uruguayan archaeology is that several localities and sites have yielded diverse kinds of Paleoindian surface finds, in particular the iconic "fishtail" or Fell points (FP hereafter), named after Fell's Cave, which was excavated by Junius Bird in the 1930s in the Magellan Basin of southern Patagonia (Bird, 1938, 1946). They have 


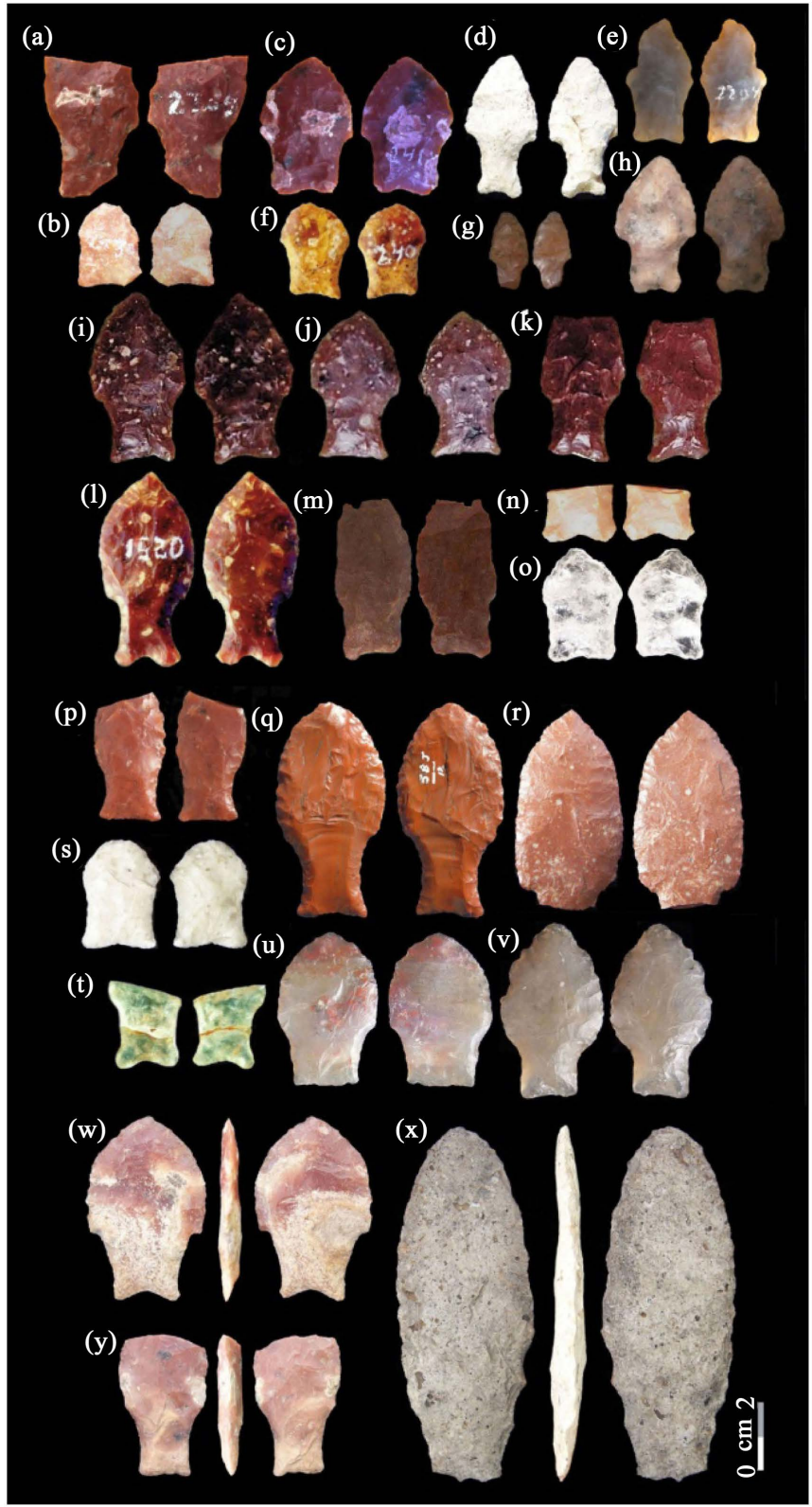

Figure 6. Examples of Fell or "fishtail" points recovered in the middle Negro River basin. ((a) and (b)) Los Molles, ((c)-(f)) Minas de Callorda, ((g)-(o)) Arroyo Cacique, (p) El Puente, $((\mathrm{q})$ and $(\mathrm{r}))$ Rincón del Bonete Lake, (s) Los Espinillos, ((t)-(v)) Collares, ((w)-(y)) Jorge O. Femenías.

been reported from Mesoamerica to southernmost South America, but are most common in the Southern Cone (Nami, 2014a, 2019a). The densest concentration has been found in Uruguay (mostly as surficial finds), crossing the Rio de la Plata in the Buenos Aires Province of east-central Argentina (Flegenheimer et al., 2014; Nami, 2017a) and from there into southern Brazil (Loponte et al., 2015, 2016). The Tacuarembó Department-especially in the middle portion of the Negro River-has yielded the highest densities of findings on surficial localities from dunes and the eroded deposits of a few stratigraphic sites. These were vi- 
sited, and following evaluation, Los Molles (LM) and Minas de Callorda (MC) were found to exhibit intact sedimentary deposits in spite of alluvial erosion, presenting the potential to discover Paleoindian occupations. Both are large sites about $1 \mathrm{~km}$ long, situated on the eroding banks of the Rio Negro close to the city of Paso de los Toros. Due to intensive erosion, hundreds of archaeological artifacts from sedimentary fluvial sections are exposed at the surface during the river's ebb. The most noteworthy finds are bifacial artifacts, mainly lithic points (Figures 6-8), including several FPs (Figures 6(a)-(f)), as well as other significant vestiges that deserve attention. At both sites, the grids were planned bearing in mind a north-south axis, and were identified using capital letters and numbers according to the cardinal points. The excavation was performed following the natural strata but using artificial levels of five centimeters. All of the findings were mapped and recorded. They were carefully examined, the most significant results being as follows.

LM ( $32^{\circ} 48.32^{\prime}$ S. Lat., $56^{\circ} 33.45^{\prime} \mathrm{W}$. Long.) is located on the mouth of Los Molles creek in the Negro River in Tacuarembó Department. Throughout the years, hundreds of flaked stone artifacts from the eroded deposit have been recovered

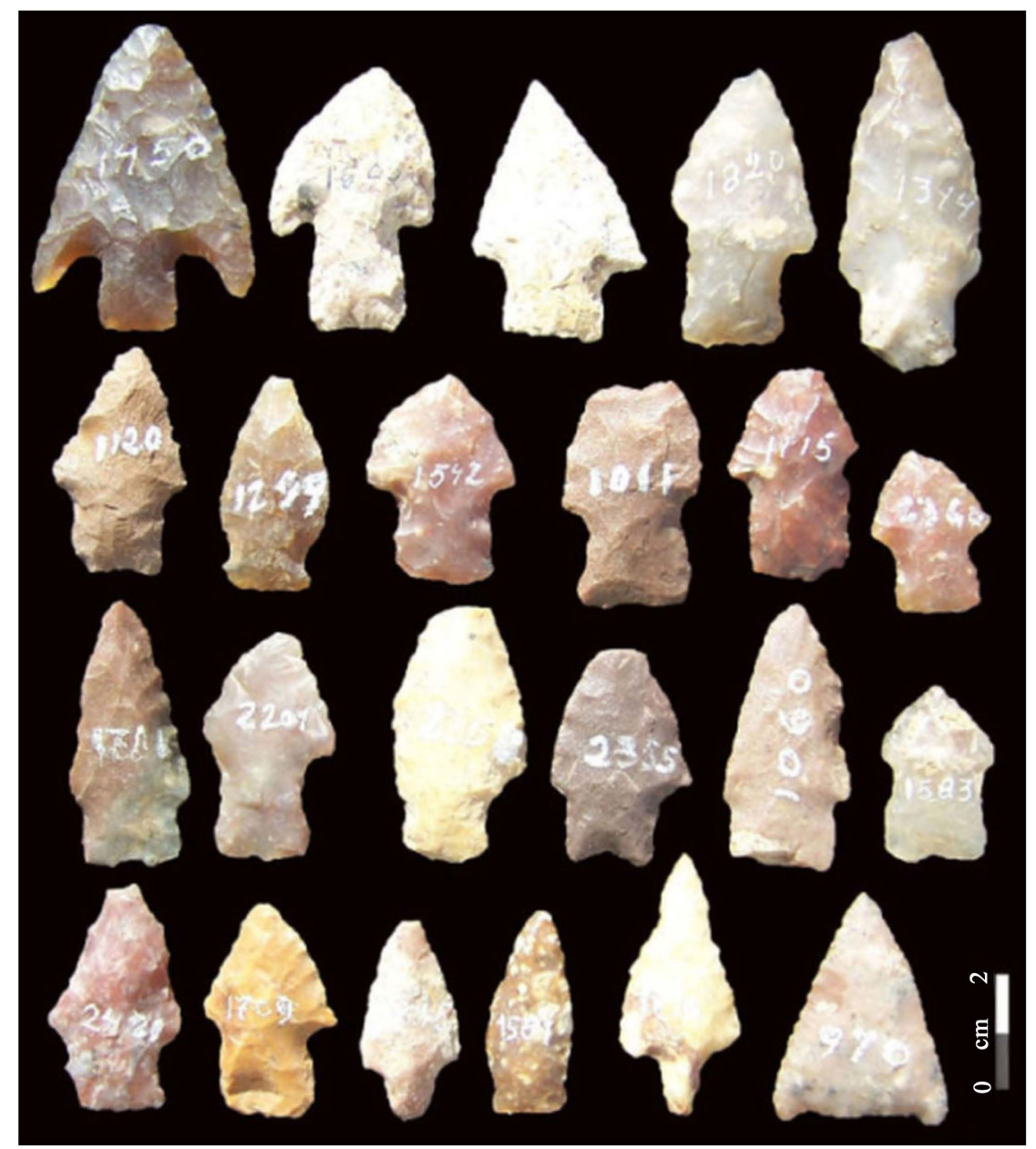

Figure 7. Diverse stemmed projectile points found at Los Molles. 


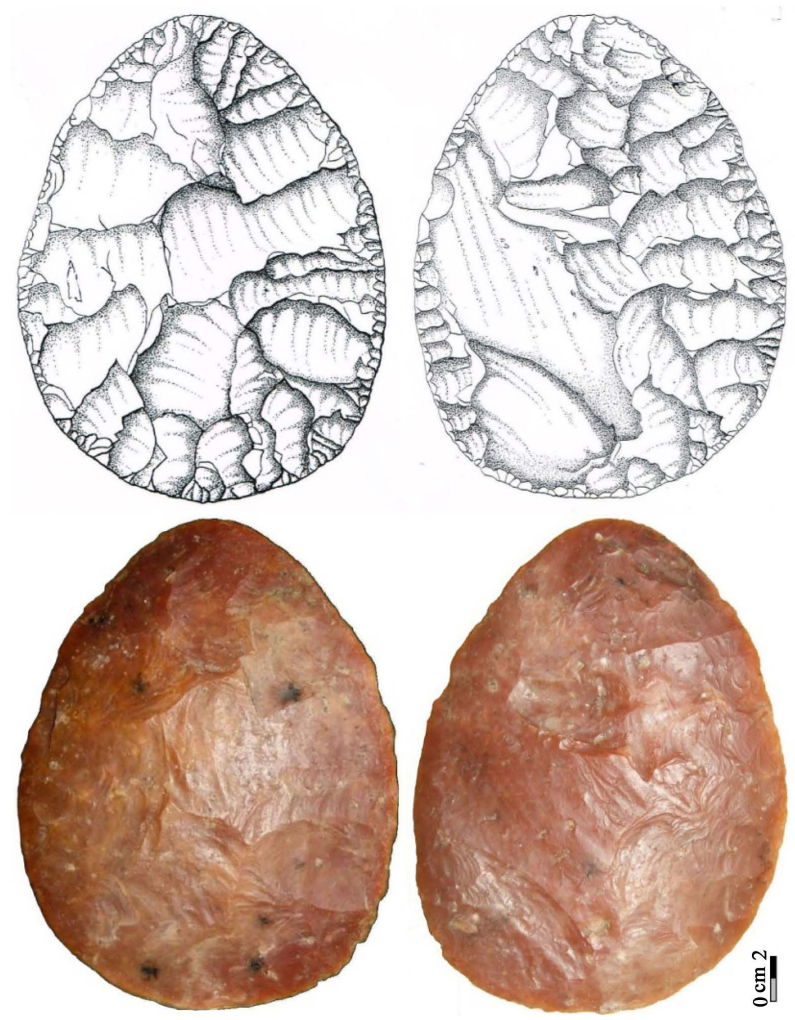

Figure 8. Drawing and image of a bifacial knife recovered at Los Molles (after Nami 2017b: Figure 2).

along the shore of the river that has destroyed part of the site and the riverbanks. The most noteworthy are well-made bifacial artifacts (Figures 6-8), such as projectile points (most of them highly rejuvenated or broken through use), including three FPs, two of which are displayed in Figure 6(a) and Figure 6(b).

The stratigraphy at LM exhibits four levels (Figure 9), which could be identified as follows: 1) the present vegetal humus surface; 2) a gray sandy layer; 3 ) a mottled sandy-loamy to loamy gray mottled deposit; and 4) a hard brown clay overlying basalt bedrock that may be comparable to the Dolores-Sopas Formation. In the excavated area of MC, the stratigraphy is similar but the hard brown clay level is $\sim 0.30 / 0.40 \mathrm{~m}$ and the bedrock lies $\sim 0.60$ to $0.70 \mathrm{~m}$ below the current soil surface, whereas in LM the deposit is thicker, ranging from $\sim 1$ to $\geq 2 \mathrm{~m}$ in depth (Figure 10). In LM, Level 4 also represents the relict of a fully developed soil suggesting a period of non-deposition and landscape stability (Holliday, 1985). In contrast to the pre-Holocene deposit, the sedimentary section containing the archaeological remains has witnessed a very low deposition rate and non-conformities due to episodic sedimentation (Dott, 1983). Subsequently, the deposits registered a discontinuous sedimentary and archaeological record with gaps since the last millennium of the Pleistocene and Holocene (Feathers \& Nami, 2018).

Although at LM some artifacts could be found in Level 2, the most abundant lithic finds start at $\sim 0.90-1.00 \mathrm{~m}$ from the datum. Most prominent are artifact 


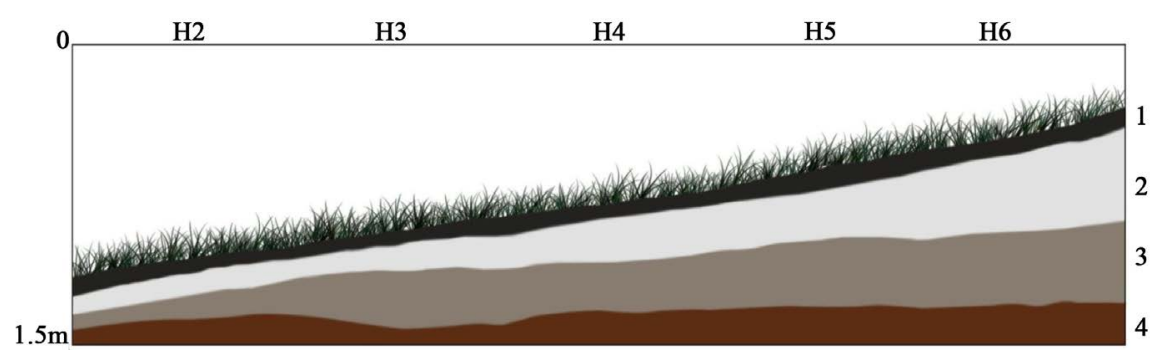

Figure 9. Example of a stratigraphic section from excavations at LM. The numbers on the right indicate the layers. The letters with a number at the top designate the grids. Graphic design in Figure 9 and Figure 10, Figure 13 and Figure 14, Figure 19 and Figure 23: H. G. Nami and G. Paez Reina.

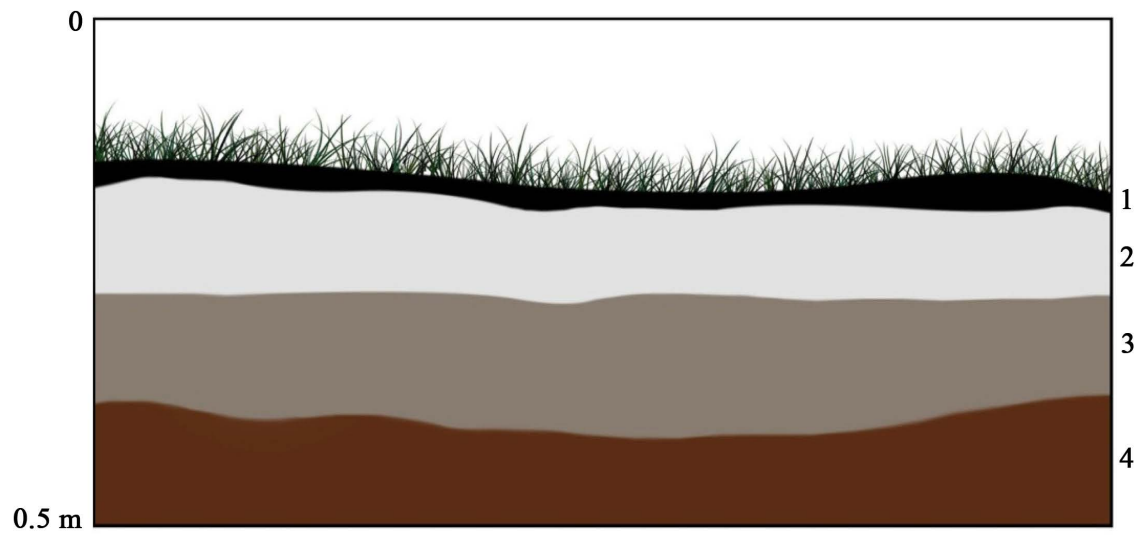

Figure 10. Stratigraphic section registered in the west profile of grid K1 from MC site. References: $0=$ Datum, and the numbers on the right indicates de layers.

concentrations at $\sim 1.15 / 1.20 \mathrm{~m}$ at the base of Level 3 and $\sim 1.25 / 1.30 \mathrm{~m}$ in the upper part of Level 4 . From a morpho-technological perspective, there are noteworthy differences between them. Lithic remains in Level 3 show unifacial tools, mainly with denticulate edges that are not very common in South American lithic assemblages. These were roughly shaped using diverse kinds of blanks, such as flakes and rounded chalcedony pebbles (Figure 11(a), Figure 11(c) and Figure 11(d)). Interestingly, they were also manufactured on prepared prismatic core-like blanks. Those made from flakes resemble Middle Paleolithic tools (e.g. Karavanić et al., 2008; Nikzad et al., 2015, Figure 4 and Figure 5), while those from core-like blanks are comparable with some scraper planes used by other traditional technologies across the world (e.g. White, 1968; Hester \& Heizer, 1972, among many others). As observed in the surveys and explorations as well through the interviews with local collectors, such diverse kinds of notched and denticulate implements represent frequent finds in the Negro River, as well as in the Tacuarembó's drainage systems (Taddei, 1969, 1977, 1985, 1987; among others). These sorts of artifacts, along with the stemmed points, are also common as surficial finds in the area. However, the lower level displays delicate side scrapers and bifacial reduction strategies manufactured on highly selected cherts. Hence, it is likely that they represent different pre-ceramic human groups. 


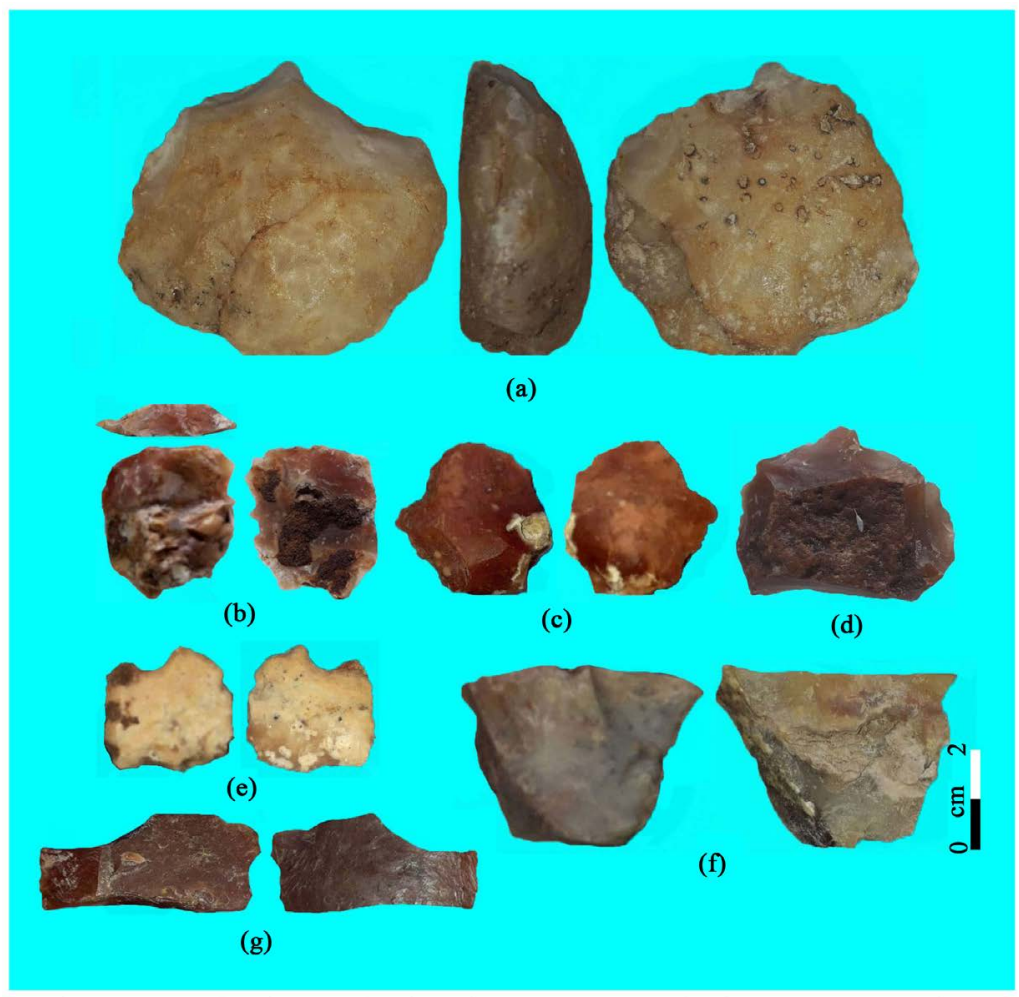

Figure 11. Examples of stone tools exhumed from level $3((\mathrm{a})-(\mathrm{e}))$ and $4((\mathrm{f})-(\mathrm{g}))$ in the LM excavation.

The archaeological remains from Level 3 can be attributed to middle Holocene foragers who used Umbu-like stemmed projectile points (Figure 7), while the lower archaeological level might be assigned to early Holocene hunter-gatherers (Figure 12) who employed similar points, but earlier Paleoindian material appears to be mixed in (Figure 6(a) and Figure 6(b)).

$\mathrm{MC}\left(32^{\circ} 51.90^{\prime} \mathrm{S}, 56^{\circ} 25.30^{\prime} \mathrm{W}\right)$ is located across the Negro River on the Durazno Department shore, immediately in front of Tacuarembó Department. Besides a dune and the floodplain flanking the river course, there is a terrace showing different sedimentary consolidated deposits (Figure 13). Like LM, over time this place has yielded hundreds of flaked stone artifacts, and local collectors have been visiting it for almost 50 years. The most significant finds are projectile points, including Paleoindian fishtail specimens (Figures 6(c)-(f)). Faunal remains are rare, but a bone fragment of an extinct species, probably of Pleistocene age, was collected at the site. Despite alluvial erosion, intact deposits appropriate for excavation remain. At MC, during the 1990s Baeza and others carried out an excavation on the alluvial plain of the river (Figure 13(1)) and identified a single Holocene archaeological component with a diagnostic find locally called a "foice" stemmed projectile point (Baeza et al., 2001). The newly excavated area (Figure 14) is located on the highest terrace of the river and about $70 \mathrm{~m}$ west, and shows a different stratigraphy of Baeza's excavation, albeit similar to the LM deposit, where the Sopas-Dolores Formation is not very deep from the surface and the Holocene alluvium (Figure 13(2)). 


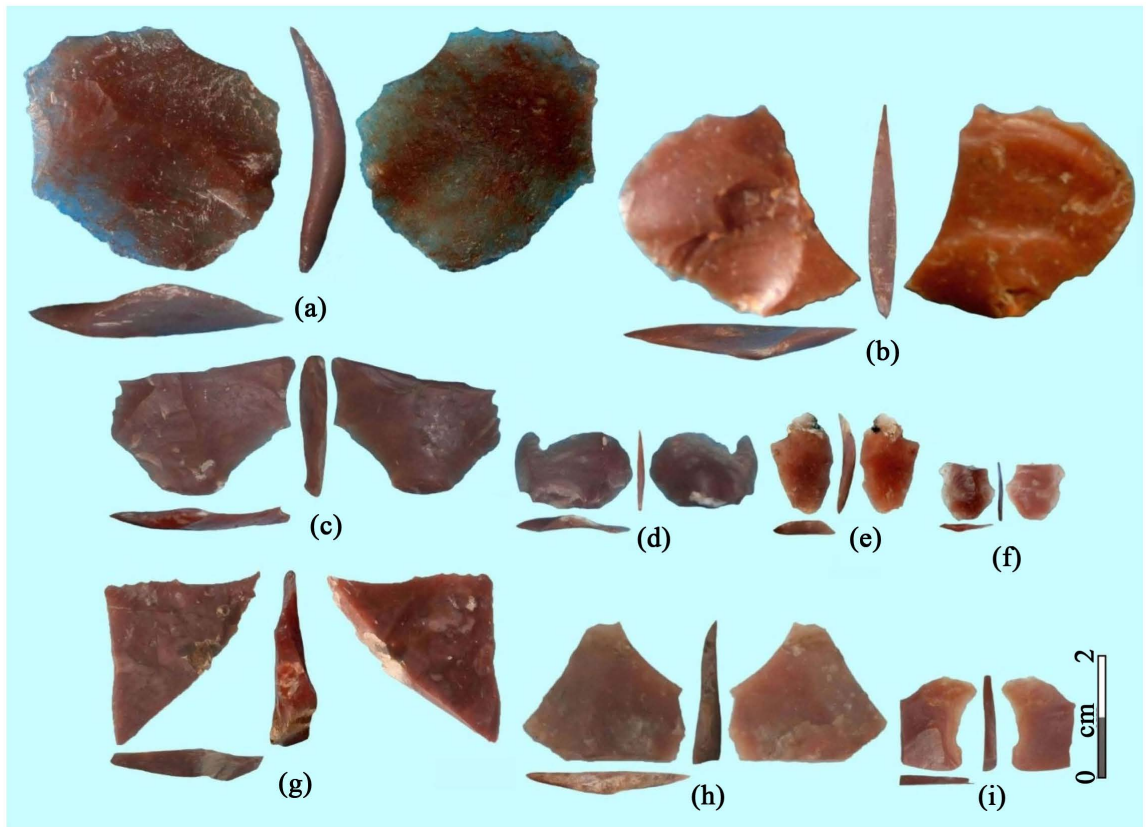

Figure 12. Bifacial archaeological debitage recovered in the lower level of Los Molles (after Nami, 2017b: Figure 21).

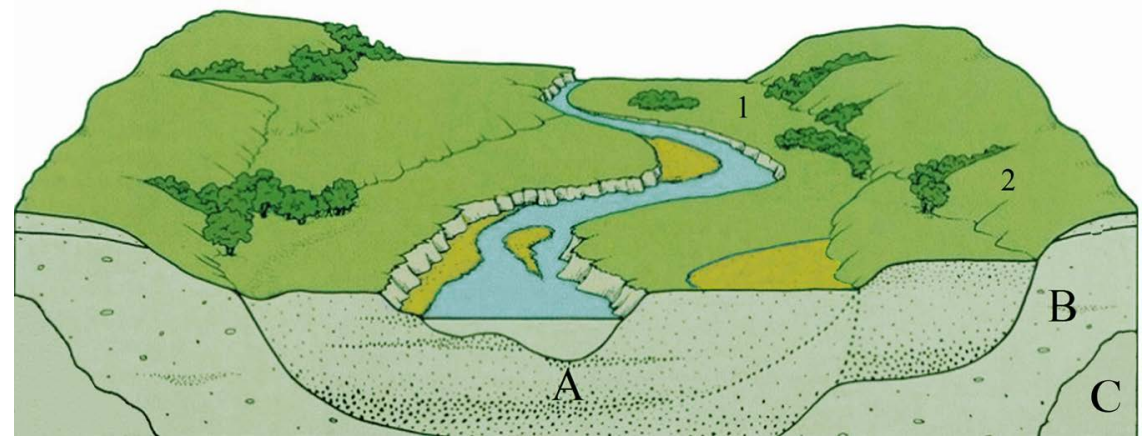

Figure 13. Idealized schematic section of the MC site, with the locations of the archaeological excavations carried out by Baeza and colleagues (1), and by the author (2). References: (A) recent alluvium; (B) Sopas-Dolores Formation; (C) basalt bedrock.

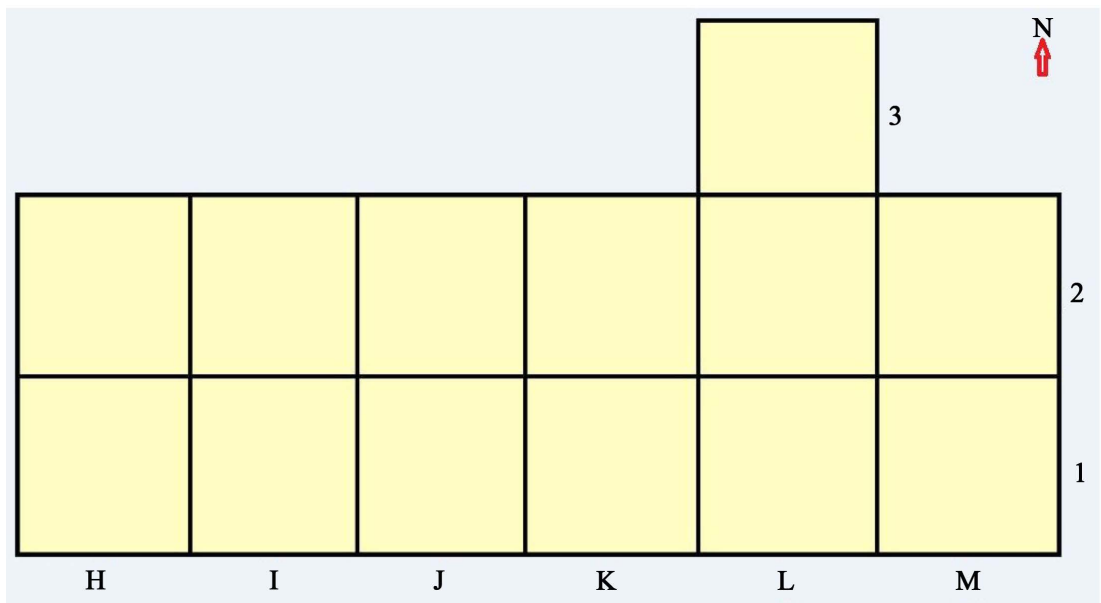

Figure 14. Grids of the archaeological excavation carried out at Minas de Callorda. 
The first remains were found at the transition between Levels 1 and 2, the second in the lower portion of Level 3, and the third at the top of Level 4. The upper level shows scattered lithic artifacts, mainly debitage. The middle one is characterized by the presence of diverse types of end scrapers, among them an unusual bifacially flaked piece and others made from short blades and used as blanks, early stages of biface manufacture, and stemmed projectile points (Nami, 2007: Figure 3(a)), which may belong to an archaeological component similar to that identified by Baeza et al. (2001). This is akin to the broadly termed "Umbu" stemmed point that characterizes Holocene lithic assemblages in the territories located in southern Brazil, Uruguay, and northeastern Argentina (e.g., Miller, 1969; Schmitz, 1987; Rodríguez, 1998, 2001; Schmidt Dias, 2007; Nami, 2016a; Okumura \& Araujo, 2014; Loponte \& Carbonera, 2019; among others). Remains from the lower archaeological level exhibits sharp technological differences from those of the upper levels. Given the length, width and thickness of significant pieces, hereafter given in parentheses, a remarkably and likely Paleoindian broken fluted base $(20 \times 27 \times 4 \mathrm{~mm})$ was found in this level. It was made on red silicified limestone by pressure flaking that left parallel flake scars on one face, while the other shows a sort of flute obtained from its basal portion (Figure 21(a)). This level probably represents the Early Holocene/Late Pleistocene hunter-gatherers. FPs and preforms have been identified in several lithic assemblages from the Negro River basin (Bosch et al., 1980; Baeza \& Femenías, 1999; Nami, 2001a, 2001b, 2009, 2013, 2017a). The majority of the remains from the top of Level 4 exhibit strong weathering, differing in this respect from the artifacts in the lower portion of Level 3.

The flaked stone artifacts in LM and MC were made from local cherts from secondary sources located along the river. About $4 \mathrm{~km}$ north of MC, around the Rincón del Bonete dam, two quarry sites have been identified. Rincón del Bonete 1 shows extensive secondary deposits of pebbles of diverse petrography and colors, ranging from 5 to $20 \mathrm{~cm}$ in diameter, among them ordinary to very high-quality cherts. Rincón del Bonete 2 is a primary source (see Luedtke, 1979) characterized by exposures of tabular nodules of silicified limestone. Flaking experiments using these rocks (Nami, 2015a, 2017a) have demonstrated that they have good to very good flaking qualities, ranking 3.5 on Callahan's (1979) lithic grade scale (see also Luedtke, 1994: pp. 86-87). Embedded in the exposed regional basaltic deposits are primary sources of white chalcedony, which were used to manufacture stone tools (Figure 11(a)). A quarry site with a certain abundance of crystal quartz nodules of varied size was recorded at Los Molles creek at about $300 \mathrm{~m}$ of the archaeological site.

\subsection{Dating Methods and Building a Chronostratigraphic Framework}

As an aspect of archaeological investigations, a crucial topic is the building of a chronostratigraphic framework through the use of various complementary me- 
thods. These comprise conventional and accelerator mass spectrometry (AMS) radiocarbon, as well as optically stimulated luminescence (OSL) dating (e.g. Nami, 2013; Feathers \& Nami, 2018). These methodologies in conjunction with regional paleomagnetic research performed on varied terminal Pleistocene/Holocene sedimentary deposits are extremely useful in constructing a chronological frame for the regional archaeological process.

The age of LM was determined via the aforementioned methods. Radiocarbon dating was performed using different materials. Level 2 under the present vegetal humus yielded two small samples of charcoal from H3 and I3 squares. These were submitted for standard assays at Gliwice Radiocarbon Laboratory, Institute of Physics (Silesian University of Technology, Poland). Both samples (Gd-30118 and Gd-3020) indicated that the charcoal was "modern". The measured radiocarbon concentration in percent of modern carbon showed a relatively high value $(133.97 \pm 0.61$ and $136.5 \pm 1.2)$ of the so-called "bomb effect". Therefore, using the CALIBomb program (Reimer et al., 2004a, 2004b), both samples could be dated to $1962 \mathrm{CE}$ or 1976-1978 CE, enabling us to ascertain that in the thinnest part of the sedimentary deposit, Level 2 was affected by the incorporation of modern material in the upper archaeological layer. From LM, a sample of sediment belonging to the upper part of Level 4 at $1.10-1.11 \mathrm{~m}$ deep was submitted for AMS dating at Leibniz-Labor für Altersbestimmung und Isotopenforschung, Universität Kiel Leibniz-Laboratory for Radiometric Dating and Stable Isotope Research (Kiel University, Germany). Its analysis yielded a $4650 \pm 30$ uncalibrated years BP (KI-5081), or 3525 - 3355 CAL BCE (Reimer et al., 2004a, 2004b). Employing the Oxcal 4.2.4 calibration program (Bronk Ramsey \& Lee, 2013) and the ShCal13 curve for the Southern Hemisphere (Hogg et al., 2013), the following ranges of calibrated ages before present were obtained: $5467-5347$ (53.9\%), 5336 - 5282 (34.0\%), 5164 - 5136 (4.0\%), and 5106 - 5077 (3.4\%) years. This date was obtained from the humic acid fraction of the sediment, which tends to provide more reliable ages for this kind of material (Ruiz Pessenda et al., 2001). However, this date yielded the apparent mean residence time (MRT) of the soil (Scharpenseel \& Schiffmann, 1977), which is the mixing of the young organic carbon with the oldest from earlier stages of pedogenesis (Stein, 1992). Consequently, the MRT indicated that the deposit was open to organic material deposition during $\sim 5$ kya. This date may be considered as a minimum age, because MRT is a significant factor that must be considered when dating soil organic matter (Stein, 1992).

In addition, sediments from LM were also subjected to OSL dating (Feathers \& Nami, 2018). For this purpose, three samples were obtained by driving PVC plastic tubes $12 \times 5 \mathrm{~cm}$ vertically inserted into a horizontal section of the archaeological excavation across the Level 3 - 4 transition in square I7 at $1.21-1.31$ $\mathrm{m}$ and 1.34 - $1.44 \mathrm{~m}$ depth from the datum (Figure 15). This ensured mixed samples. In the same grid, a third sample was horizontally taken at $\sim 20 \mathrm{~cm}$ below the lower archaeological level at $-1.65 \mathrm{~m}$ depth. The samples were submitted 


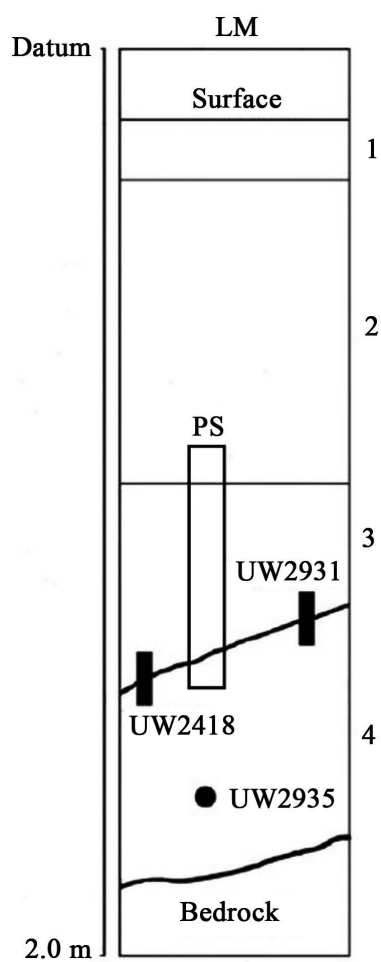

(a)
PFFCC

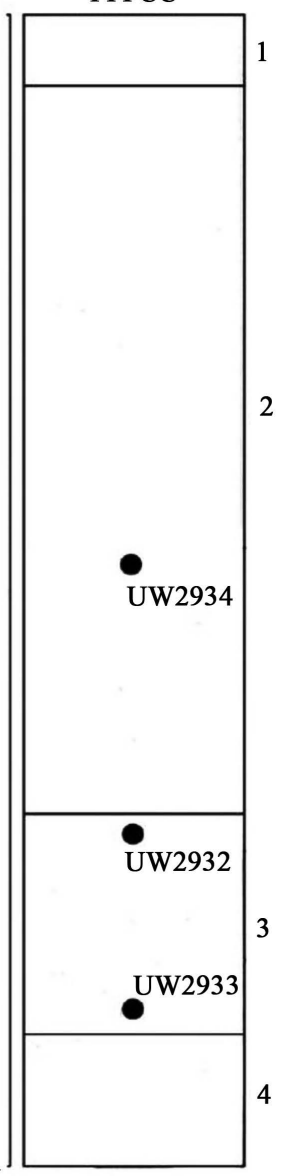

(b)

Figure 15. Schematic sections of LM (a) and PFFCC (b) sites showing the location of the OSL samples. The rectangle at LM denotes the paleomagnetic sampling (PS). The numbers on the right indicate the stratigraphic levels (slightly modified from Feathers and Nami, 2018: Figure 4).

and processed at the Luminiscence Dating Archaeology (University of Washington, USA). The results are presented in Table 1. Samples UW2918 and UW2931 yielded two ages, separated by 3.55 to $4.96 \mathrm{ka}$, respectively, reflecting a geological unconformity surface, as suggested by the relict of a fully developed soil observed at the upper portion of Level 4 (Feathers \& Nami, 2018). The few local archaeological buried records obtained from sedimentary sequences also revealed episodic sedimentation and contained unconformities (Baeza et al., 2001; Nami, 2007). The youngest OSL dated from both samples was consistent with the minimum age obtained from the soil with AMS dating at the top of Level, 4 confirming that this level is a terminal Pleistocene/Early Holocene deposit. The age of Level 3 agrees with the AMS result, meaning that the archaeological component from this horizon belongs to the Middle Holocene. On the other side, the archaeological vestiges embedded in the transition of Levels $3-4$ and the upper part of 4 is an early Holocene occupation that used stemmed projectile points in its weaponry (Nami, 2007: Figure 3(a); Feathers \& Nami, 2018). 
Table 1. OSL ages obtained from the samples taken at LM and PFFCC sites.

\begin{tabular}{cccc}
\hline Site & Sample & Level & Ages (ka) \\
\hline & UW2931 & Transition 3/4 & $4.18 \pm 0.32$ \\
\multirow{2}{*}{ LM } & & & $9.14 \pm 0.77$ \\
& UW2418 & Transition 3/4 & $5.39 \pm 0.97$ \\
& UW2935 & 4 & $11.8 \pm 0.8 \pm 0.83$ \\
\hline \multirow{2}{*}{ PFFCC } & UW2934 & 2 & $1.04 \pm 0.08$ \\
& UW2932 & 3 (top) & $2.12 \pm 0.15$ \\
& UW2933 & 3 (base) & $4.24 \pm 0.29$ \\
\hline
\end{tabular}

Crossing the Negro River, another site dated with this method was Puente del Ferrocarril (PFFCC, $32^{\circ} 49^{\prime} 20.03$ S. Lat. $56^{\circ} 30^{\prime} 48.01 \mathrm{~W}$. Long.) which is situated across a railway bridge south of Paso de los Toros in Durazno department (Figure 5(b) and Figure 5(c)). Non-diagnostic scattered archaeological artifacts are found along the riverbanks eroded by the new course of the river after the dam construction. A sedimentary section about 2-2.5 m thick shows the following layers: 1) the present vegetal humus surface; 2) a clear brown sandy layer; 3 ) a dark gray/black clayed stratum, and 4) hard brown clay overlying the basalt bedrock (Figure 5(c), Figure 15(b)). The latter was tentatively identified as the Sopas-Dolores deposit. The obtained dates are depicted in Table 1. As an additional component of the local chrono-stratigraphical framework, the earliest date at Puente del FFCC agrees with the ages for Stratum 3 at Los Molles. This sample lies just above the suspected Sopas-Dolores formation; if it is right, then there is an unconformity reflecting no sedimentation for several thousand years. The later dates reflect a younger record that is missing at LM and poorly known in the Middle Negro in general. Along with the AMS date from La, they may also provide local ages for wetland deposits observed in other areas in Uruguay during the Holocene.

Paleomagnetism is another powerful discipline useful for establishing absolute or relative chronologies on varied kinds of sedimentary deposits (Herz \& Garrison, 1998; Merrill \& McFadden, 2005). Besides visiting diverse localities for evaluating its importance in archaeological research, a significant aspect of my investigation was to find exposed geological sections to carry out paleomagnetic studies. Hence, this investigation was performed to construct regional curves of paleosecular variations with chronostratigraphic purposes (e.g. Nami. 2006a, 2008, 2011a, 2012).

Several vertical paleomagnetic samplings were performed to study the regional geomagnetic field (GMF) directions. To collect samples, cylindrical containers (2.5 $\mathrm{cm}$ long and $2.0 \mathrm{~cm}$ in diameter) overlapping each other by about 50 percent were carefully pushed into the sections (Figure 16). Despite the fact that the paleomagnetic analysis remains in progress, some preliminary results can be reported. These were obtained from the samplings taken at the LM site and Larrachea (La), 


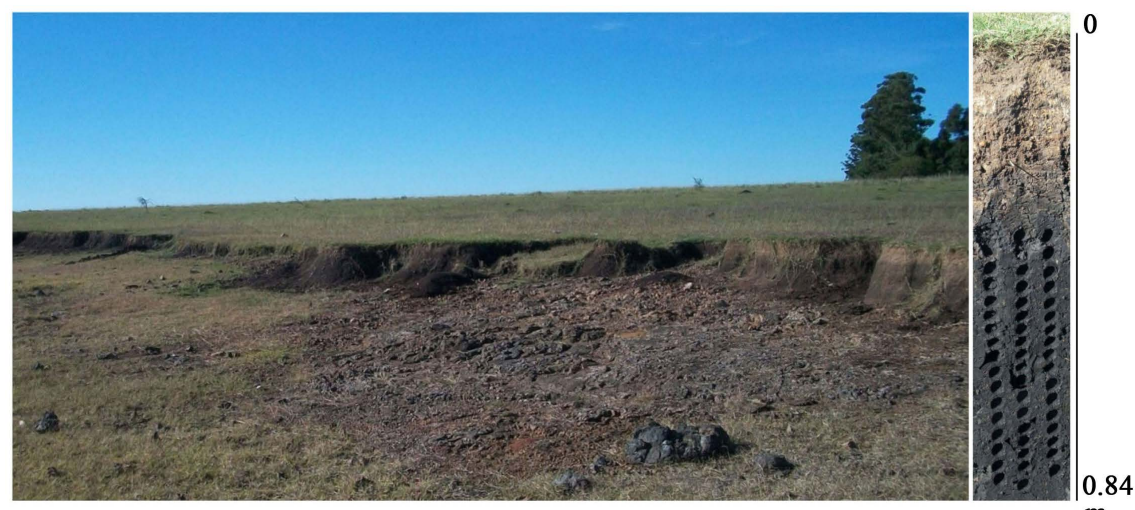

Figure 16. Examples of the Larrachea sedimentary section with detailed paleomagnetic sampling observed on the right.

an archaeological locality that yielded a FP (Figure 17(a), Nami \& Yataco Capcha, 2020) and ubiquitous Umbu-like specimens, most of them resharpened and/or broken through impact (Figures 17(b)-(m)). At both sites, the samples showed oblique reverse polarity directions far from the present dipolar field, suggesting that the normal direction of the GMF was interrupted by a short time excursion (Nami, n.d.a). The ages from LM and an AMS radiocarbon assay made from the humic fraction of the La sediment yielded a minimum date of $~ 3.5$ kya for the sampled deposit, suggesting that the geomagnetic event occurred during the middle Holocene at $\sim 4$ - 5 kya. These results are in agreement with the presence of an anomalous GMF behavior observed across the Southern Hemisphere during the terminal Pleistocene and early, middle and late Holocene (Nami, 2012, 2015b, 2019b; Nami et al., 2016, 2017, 2020). Particularly in this region, the existence of this anomaly has been suggested by a wide pulse in declination during the middle Holocene in previous studies undertaken at the Uruguay River shore in southeastern Corrientes Province on the Argentine-Uruguayan border (Nami, 2011a: Figure 7). Furthermore, as displayed in Figure 18, a sample from the Santa Lucia site showed that despite not useful to isolate a direction, it carried two magnetic components indicating that the vector changes from negative to positive inclinations (intermediate or reverse), moving in a great circle. This was confirmed by the detailed paleomagnetic records obtained at LM and La revealing paleosecular variations during the time of anomalous behavior, with a $\sim 180^{\circ}$ difference in directions with the present normal GMF. Although the results of this investigation have not yet been published (Nami, n.d.a), Figure 19 illustrates the mean virtual geomagnetic pole (VGP) positions obtained at both sites compared with other Early Holocene ( 9.2 kya) mean VGP positions obtained at Barrancas de Maipú in western Argentina (Nami et al., 2017). Interestingly, despite a $\sim 4$ - 5 ky difference, they are located in and close to Oceania, a fact that also happens in several geomagnetic excursions and polarity transitions occurred in Earth history (e.g. Hoffman \& Singer, 2004; Gurarii, 2005; Laj \& Channell, 2007). 


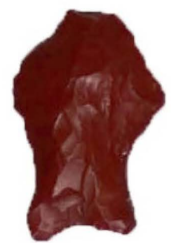

(a)

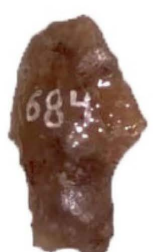

(e)

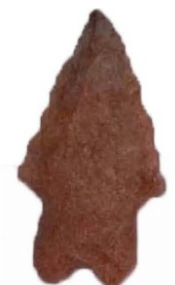

(j)

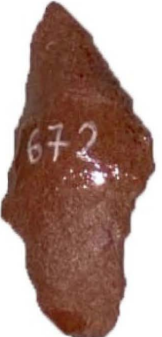

(b)

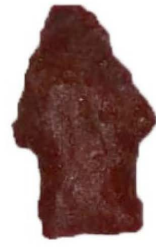

(f)

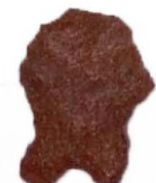

(k)

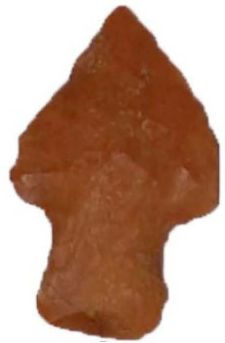

(c)

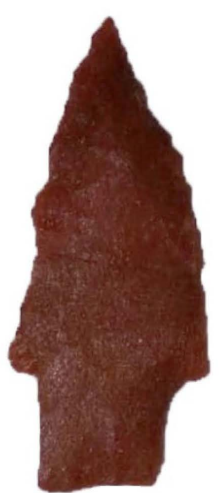

(d)

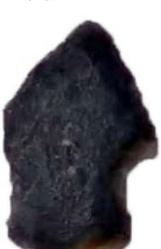

(i) (g)

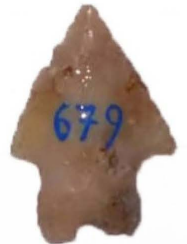

(1)

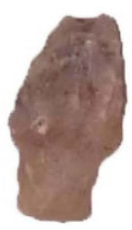

(h)

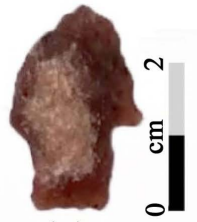

(m)

Figure 17. Armature tips found at Larrachea archaeological locality. (a) Fell, ((b)-(m)) stemmed Umbu like points.

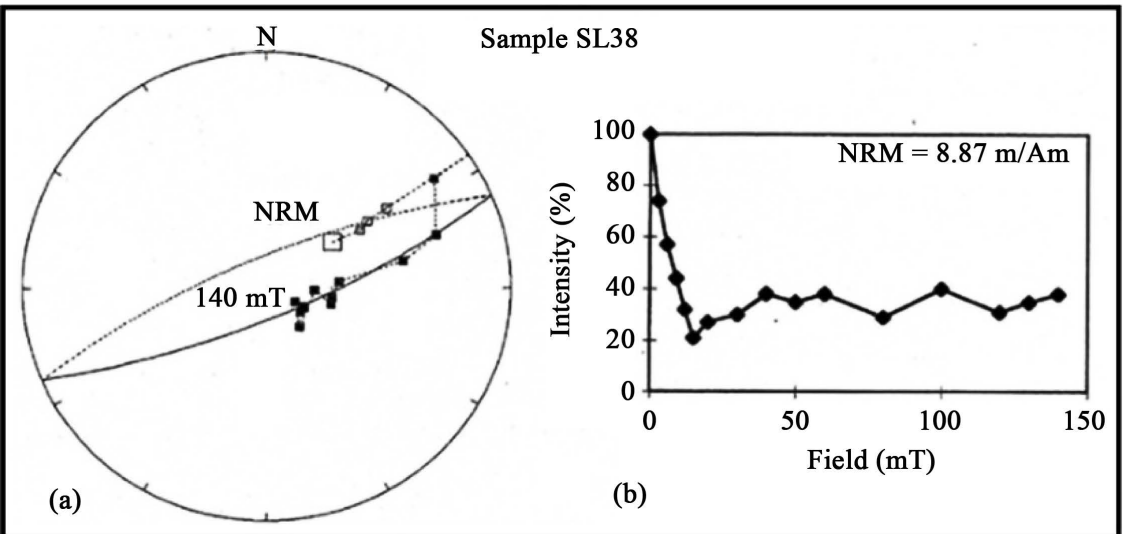

Figure 18. Great circle (a) and curve (b) observed during the demagnetization process of the SL38 sample (after Nami, 2011a: Figure 4).

A number of paleomagnetic studies conducted at different sites belonging to diverse sedimentary environments in the Southern Cone of South America have yielded normal, intermediate and reversed directions. This suggests that in southern South America during the Early, Middle and Late Holocene, the Earth's magnetic field probably underwent short-lived excursions (Nami, 1995a, 1999, 2019b; 


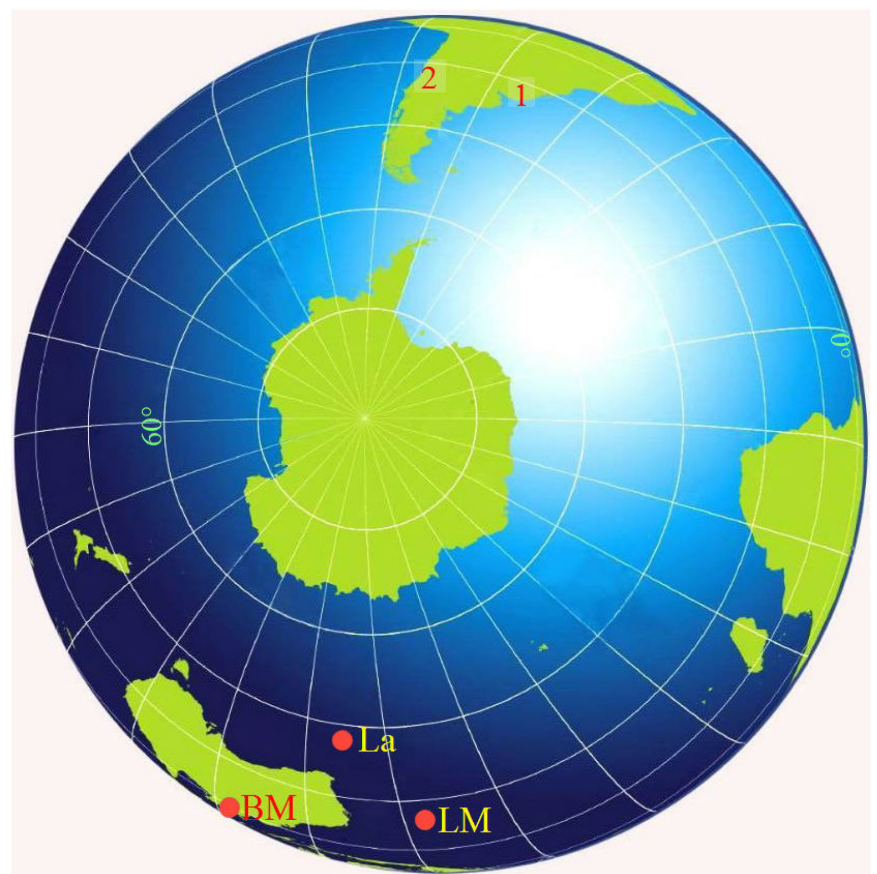

Figure 19. Location of mean virtual geomagnetic poles calculated from continuous records with oblique directions from Los Molles, Larrachea (Uruguay) and Barrancas de Maipú (Argentina).

among others). Similar events have been identified in different sections and materials from Eurasia and North and South America. This may suggest that some anomalous geomagnetic phenomena have occurred globally during the more recent geological epoch. In fact, during the last $~ 11 / 10$ kya, the normal polarity of the Earth's magnetic field has been interrupted by several short-lived reversed polarity events (Nami, 2012). In this scenario, the observed anomalous directions at La and LM might be another short-term manifestation of this process, corresponding to a Late/Middle Holocene excursion. In other words, anomalous GMF directions at the sampled sites suggest that they were recorded during the Late/Middle Holocene (Nami, 2012). Therefore, they reinforce and complement the ages reported above.

In summary, the paleomagnetic results obtained at La and LM can be interpreted as additional paleomagnetic regional records in southeastern South America (e.g. Nami, 1999, 2006a, 2011a, n.d.a). In addition to the expected normal directions, some of them show significant directional changes in declination and inclination with intermediate and reverse VGP positions during the terminal Pleistocene and Holocene (e.g. Nami, 1995a, 1999, 2011a, 2019b; Nami et al., 2017). Therefore, these results should simply be interpreted as chronostratigraphic tools. Hence, if the anomalous directions do represent an excursion, this may also be used as a dating device, rendering it an excellent magnetostratigraphic marker for the period when this event occurred, and serving to correlate regional stratigraphies and calibrate relative and absolute chronologies (Tarling, 1983; Herz \& Garrison, 1998; Merrill \& McFadden, 2005). 


\subsection{Investigations into Stone Tool Technologies}

The mid-eastern part of southeastern South America in southern Brazil, northeastern Argentina, and Uruguay indicates that human populations living in the area since the terminal Pleistocene had a remarkable lithic technology. Indeed, the archaeological record is characterized by the existence of flaked stone tools of extraordinary manufacture, revealing their makers' elevated technical knapping skills (e.g. Okumura \& Araujo, 2014; Lourdeau et al., 2017; Nami, 2013, 2017b; among others).

The area under study reveals an abundant lithic record traditionally classified in terms of rigid and intuitive morphological typologies. Despite its important quantity and quality, a lack of in-depth studies from a contemporary viewpoint is apparent. In response, several trips were performed to the cities of Paso de los Toros and Tacuarembó, respectively located in the northern and southern parts of the department. The technological investigations were carried out from observational and experimental perspectives. The former was not only performed on artifacts recovered in systematic excavations, but also by studying institutionally and privately curated collections, mostly made from surface finds recovered in known and unknown sites and/or localities. Additionally, once significant evidence to deepen the aforementioned topics had been discovered, I visited the locality and/or the sites where they were found whenever possible.

The abundant lithic remains found at Tacuarembó were left by the different hunter-gatherers societies living in the area during the last 11 kya. An important number of artifacts may be used to discuss issues of archeological relevance from the technological and functional viewpoints. Consequently, to deepen existing knowledge of the lithic morpho-technological variability of the regional archaeological record, the following are detailed observations and salient information on a number of remarkable artifacts that deserve attention.

Several Paleoindian artifacts were recently registered and analyzed. In the Negro River basin, these usually come from eroded sedimentary sections likely belonging to the Late Pleistocene Sopas-Dolores Formation, or the sites located in the above-mentioned dunes at the river shorelines. In actuality, numerous archaeological artifacts were found, suggesting the extensive use of the dunes by prehistoric societies. Just as in other times and places around the world (e.g. Bórmida, 1968; Jodry, 1999; Burley, 2005; Kandel \& Conard, 2013), at Tacuarembó the dunes were highly significant in their life-way since the earliest human occupations by some reason that must be seriously explored.

The new observations were realized on pieces belonging from the following collections: Mr. Justo Olivera curated at the Museo del Indio (Tacuarembó city), Mr. Segundo Ademar "Pocho" Muga Prieto (currently Museo Histórico Casa Muga, San Gregorio de Polanco village), and Mrs. A. Castillo, R. Cáceres and F. Moreira. These studies permitted the identification of new exemplars of extreme technological interest. Paleoindian diagnostic FPs has been recovered at surface sites all across Uruguay, but the main concentration is in its central part, espe- 
cially in the Negro River basin. Besides being an important place for the colonizers' groups, this fact is also probably due to a geo-archaeological artifact, because the construction of the dam has raised the river's level and eroded the old sites located on some of its terraces. The study of the recently identified FPs has enabled knowledge to be advanced of its morphological variability, technology, and function (e.g. Nami, 2009, 2010, 2017a; Nami \& Castro, 2010; Nami, 2014a; among others). Like in other parts of South America (e.g. Bell, 1965), the Uruguayan record shows that besides the "typical" fishtailed forms, there is broad variation both in terms of stems and blade shapes (Nami, 2014a). In many cases, the precise location of the FPs has not been registered or only a very general location is known, so interpretations must be treated with caution (cf. Suárez \& Leigh, 2010; Femenías et al., 2011). Despite recovery by non-professionals, these data may be used to gather valuable technological information from several viewpoints. In this regard, a very interesting piece is a variety of FP (Figure 20(a)) that was found at La Fuzarca, a site on a dune on the Tacuarembó River shoreline. This specimen $(58.2 \times 33.4 \times 9.4 / 8.6 \mathrm{~mm})$ is made from sandstone, a material available in northern Tacuarembó as well in the neighboring departments to the north. Due to its shape, this exemplar is comparable with the so-called

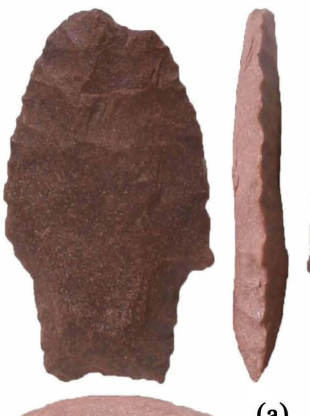

(a)
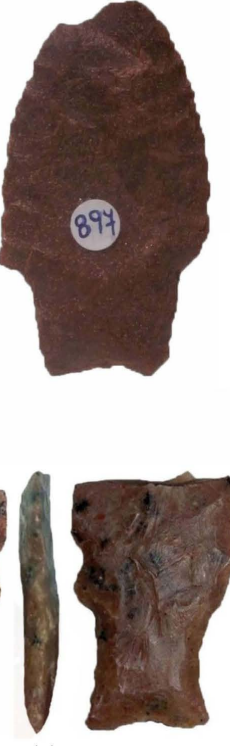

(c)
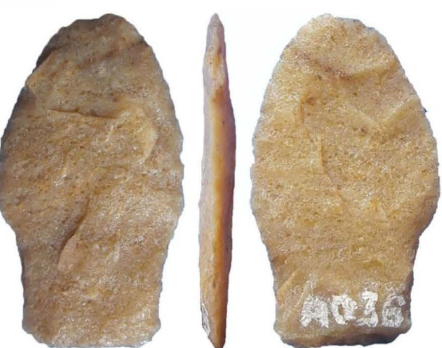

(b)
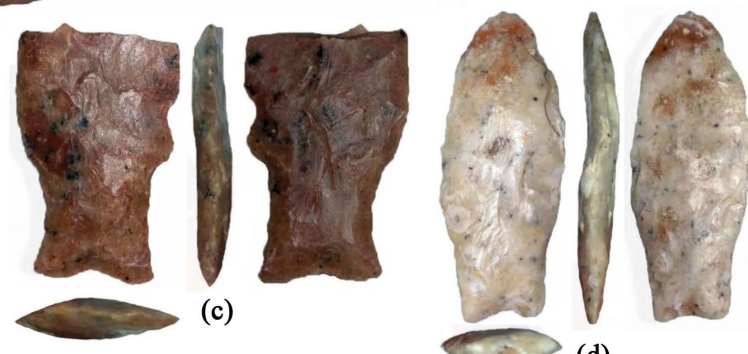

(d)
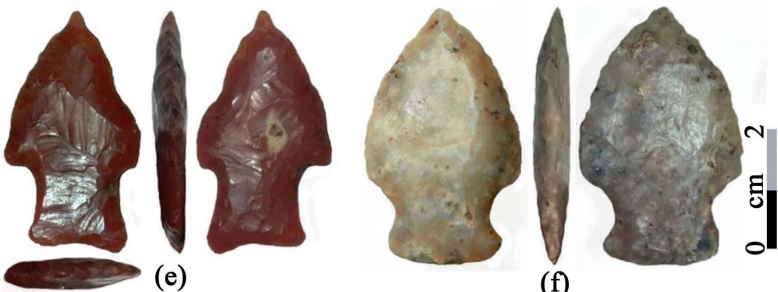

(f)

Figure 20. Fell points (a)-(d), and possible exemplars (e) and (f), found in Tacuarembó Department. (a) La Fuzarca, (b)-(d) San Gregorio de Polanco, (e) and (f) unknown origin. 
"El Inga broad stemmed", which is an FP variant characterized by a wide stem and generally with straight borders (Nami, 2014a, 2014b), but which is sometimes not recognized and documented as an FP. Interestingly, as displayed in Figure 20(b), another comparable piece has been collected by Mr. Muga in San Gregorio de Polanco village on the shore of the Negro River. This FP $(56.8 \times$ $32.9 \times 6.4 \mathrm{~mm}$ ) is made from quartzite on a previously thinned biface blank. Both items show an impact cone initiating fracture in the tips (Weitzel et al., 2014: p. 91). Also probably broken by impact is a unit with a "typical" stem defining the FPs found at San Gregorio de Polanco village (Figure 20(c)). With the same origin, another interesting lanceolate FP $(55.5 \times 22.2 \times 7.1)$ shaped on a flake of whitish-gray silcrete is presented in Figure $20(d)$. Olivera's collection contains two armature tips of unknown origin, which due to some of their general characteristics might be deemed FPs. One is displayed in Figure 20(e), presenting a straight shoulder, and made using a red material, a color preferred by the colonizers for use in their weaponry FPs (Nami, 2017a). In the other specimen, apart from the convex stem's base, the rest of its techno-morphological attributes agree with the points in question (Figure 20(f)). Both items, on one of its faces, show short flutes and were finished by short pressure retouches applied by pressure on previously bifacially thinned preforms.

Significant is an unusual piece (Figure 21(b)) from a small dune on the shore of the Tacuarembó Grande River, $60 \mathrm{~km}$ north-east of Tacuarembó city by Route 26. It is a triangular bifacial flaked specimen $(67.2 \times 31.4 \times 6.4 \mathrm{~mm})$ made from fine-grained sandstone. It manifests pressure flaking on both faces applied to a previously thinned biface by percussion that in the center of its basal part has a prepared platform with a nipple from which a relatively short flute has been detached. Due to these features, it could be identified as a possible unfinished Paleoindian point. Another broken-fluted preform was recently found at a site on the north shore of the Rincón del Bonete dam. Exhibited in Figure 21(c), this piece represents the basal portion of a preform broken by a reverse hinge fracture produced during fluting (Nichols, 1970). It is made from a fine-grained gray silcrete commonly used in the region to manufacture early tools (Nami, 2017a). At this point, it is worth recalling that in the early 2000s several fluted preforms and one prepared nipple were identified in the Cerro de los Burros locality (southern Uruguay), as well as Paso del Puerto, a dune site located in the Negro River basin at the eponymous department (Nami, 2001a, 2001b). Like the newly reported items, several of these showed parallel borders and beveled bases, some with isolated nipples for fluting (e.g. Figure 21(d) and Figure 21(e)). It is also important to mention that similar platform preparations in FP making have been recorded in many places across South America (e.g. Nami, 2014b: Figures 10-15; Nami, 2016a: Figures 2(c)-(e)).

Another documented instrument is a noteworthy unifacial implement that is rare in the Uruguayan archaeological record (Figure 22). It is an example of a remarkable multipurpose tool, usually called knives and side-scrapers, found across the country, with striking technological and typological similarities with 
(a)

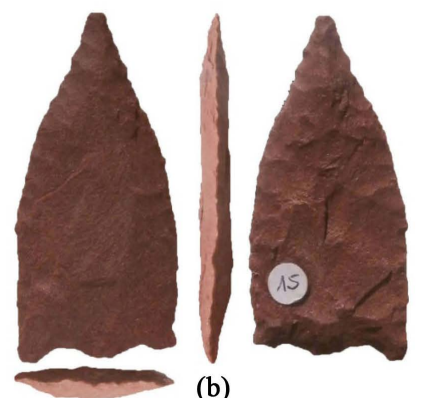

(b)
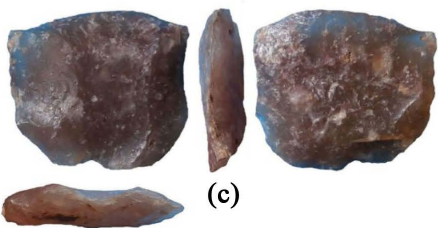

(c)

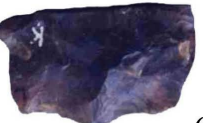

(d)

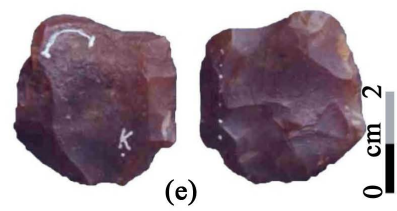

Figure 21. Paleoindian preforms showing fluting and prepared platforms by isolating a nipple. (a) Minas de Callorda, (b) Tacuarembó Grande River, (c) Rincón del Bonete, (d) and (e) Paso del Puerto.
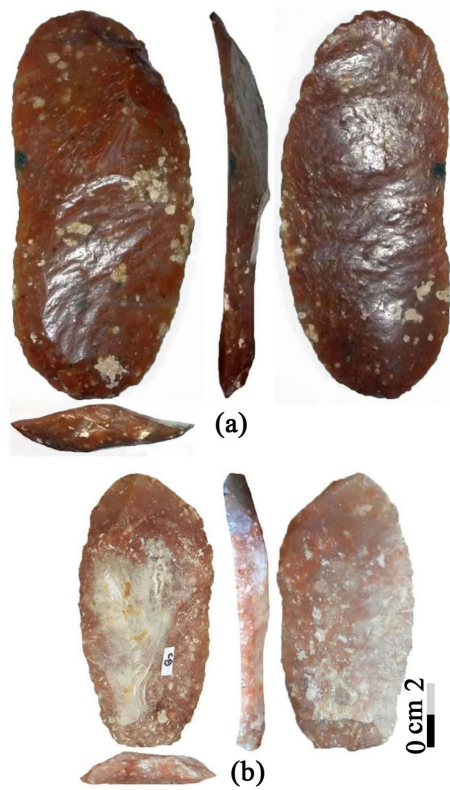

(b)

Figure 22. Highly possible Paleoindian unifacial tools. (a) Tacuarembó Department; (b) Cañada El Bravío. 
pieces from surface and stratified FP sites in the Southern Cone (e.g. Nami, 2019a). In this regard, as displayed in Figure 22(a), one specimen $(97.7 \times 43.9 \times$ $9.5 / 6.3 \mathrm{~mm}$ ) from Olivera's collection might be considered as a tool of the Paleoindian lithic assemblage (Nami, 2013, 2014a, 2017b). In general, they are well-made from thin flake blanks that were probably obtained from some sort of prepared cores (e.g. Nami, 2006b, 2013, 2017a, 2017b). They are also mostly manufactured using reddish silcrete, a raw material preferred by the colonizers (Nami, 2017a). Curiously, crossing the Negro River a similar piece was recently identified in the Soriano Department, where interesting Paleoindian remains have also been recovered (Nami, 2017b). Illustrated in Figure 22(b) and also manufactured from silcrete, this piece comes from a small watercourse called Cañada El Bravío, a place where significant bones of extinct Pleistocene fauna have been collected.

Situated on the banks of a small stream that bears the same name (Figure 23), La California (LC) is a quarry-workshop site (Figure 24) located $38 \mathrm{~km}$ northwest of Tacuarembó city in the northern part of the department. Here there are extensive outcrops that constitute a primary source (Luedtke, 1979) of silicified sandstone, where a large number of archaeological artifacts can be observed at the surface, as well as being buried in a level of black sediment overlying the sandstone bedrock (Figure 23(2)). Useful to know the first stages in stone tool production (Ericson \& Purdy, 1984), the remains observed at LC mainly consist of cores and waste, implying that this part of the production process was performed here, as suggested by several archaeological, experimental, and ethno-archaeological investigations (e.g. Callahan, 1979; Binford, 1986). In this regard, a remarkable discovery was the presence of well-prepared Levallois-like cores to detach predetermined flakes. Since the discovery of the employment of such cores and their variants in the Southern Cone of South America (e.g. Nami, 1992, 1995b), they have been documented in several localities below the Tropic of Capricorn, particularly in Uruguay (Nami, 2013). However, among the great

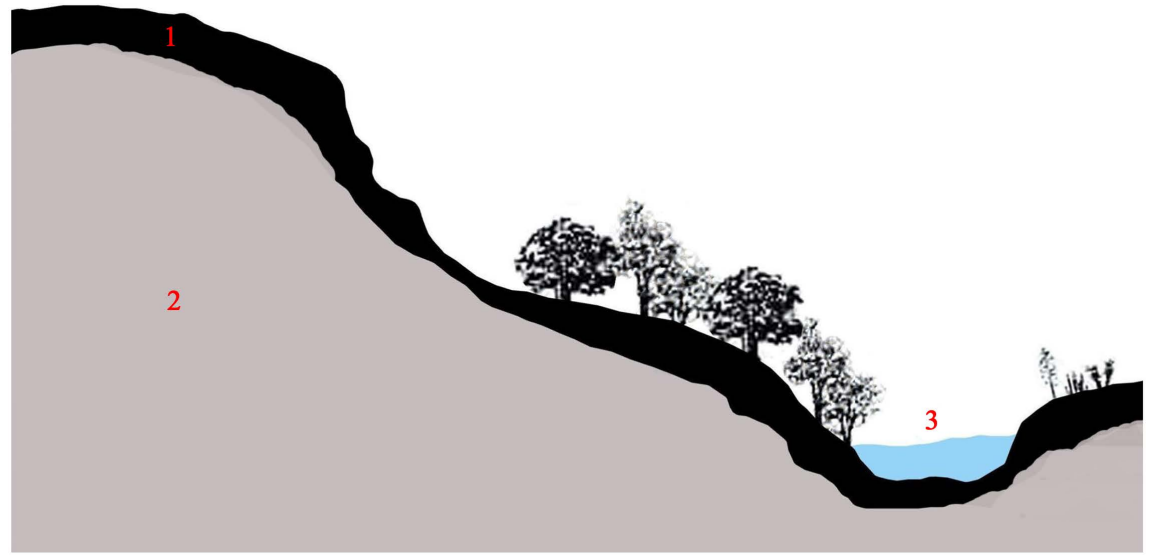

Figure 23. Schematic transversal section of the archaeological black sedimentary level (1) containing the archeological remains in the quarry-workshop site in relation to the sandstone bedrock (2) and La California creek (3). 


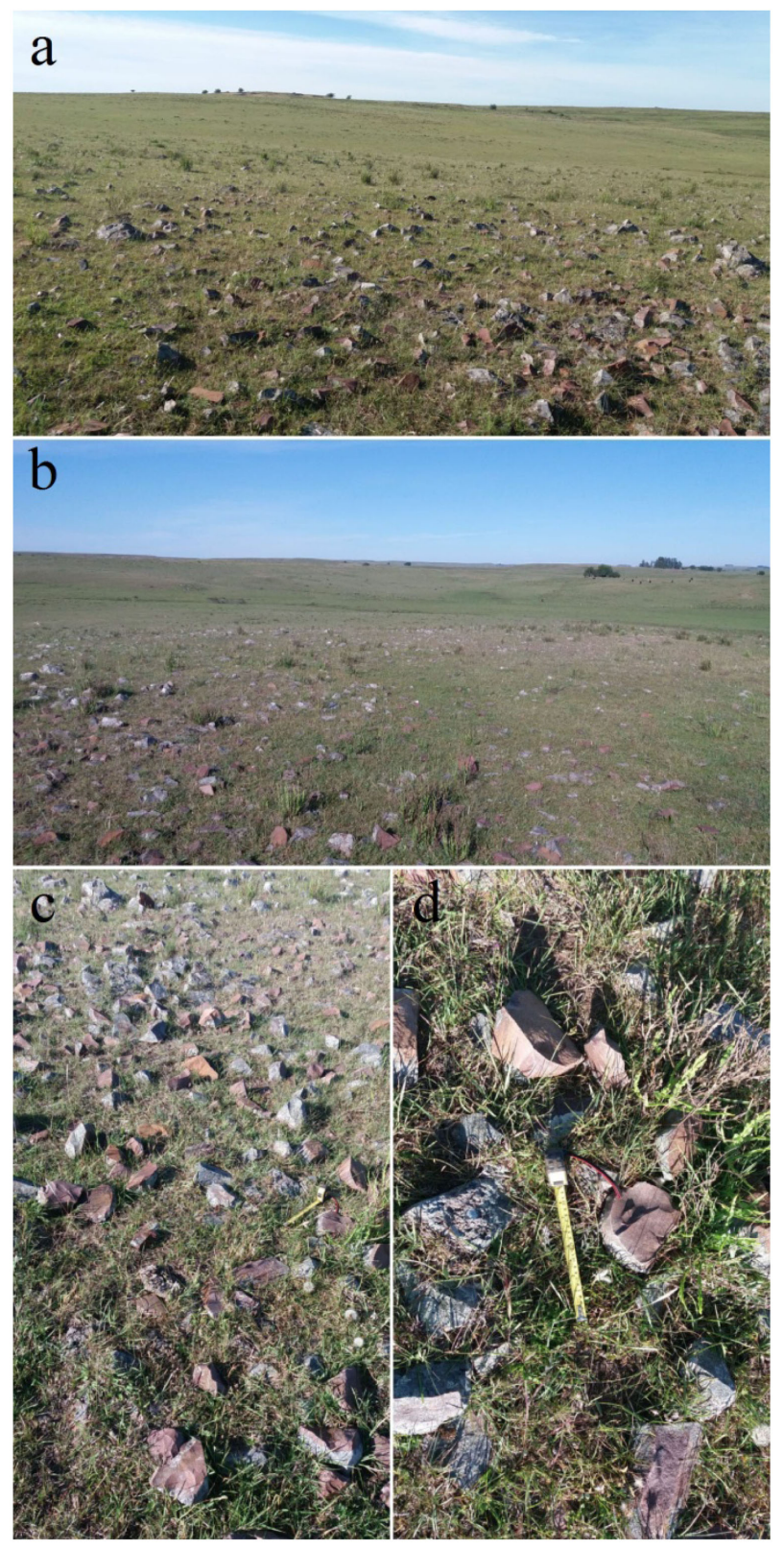

Figure 24. Different views of the La California quarry-workshop site. (a) and (b) General perspective of the flaking waste observed at the surface of the site. (c) and (d) Images of the different kinds of remains resulting from the first step in the stone tool production process.

variety of shapes, the Levallois-like core presence was documented with a number of specimens. Figure 25 displays two excellent examples of predetermined flakes detached from a previously prepared core. The specimen $(107.4 \times 115.4 \times$ $62.1 \mathrm{~mm}$ ) exhibited in Figure 25(a) shows a clear flake scar left by a flake detached from a shaped striking platform by isolating a point of percussion of $\sim 85^{\circ}$ where the blow was applied to obtain it. In the lower panel of the same figure, a "turtleback" core $(104.2 \times 101.4 \times 33.0 \mathrm{~mm})$ with two flake extractions can be seen, one on each face, the main one being obtained from a platform of $\sim 82^{\circ} / 83^{\circ}$. 


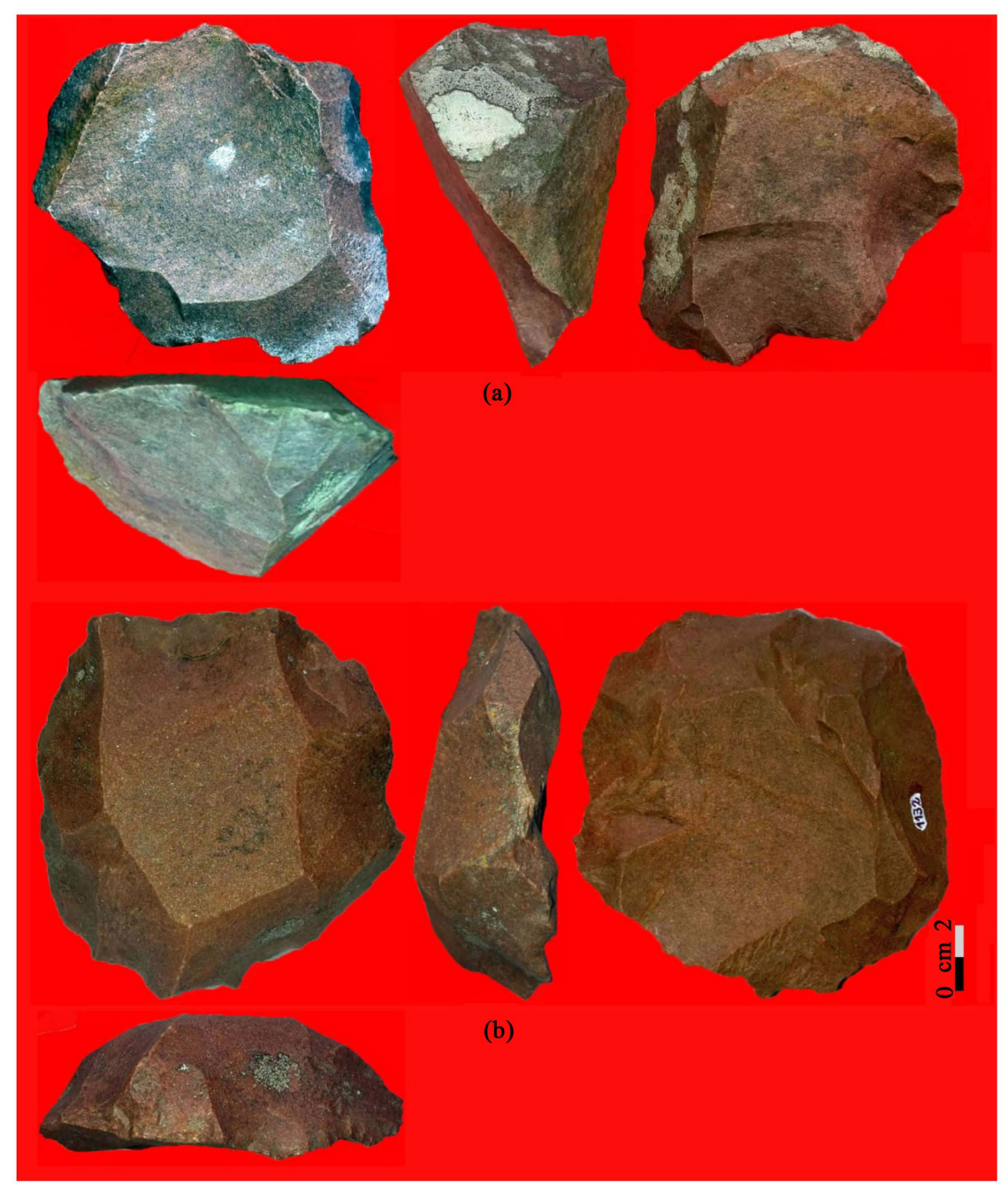

Figure 25. Levallois-like cores from La California site.

Found at El Tala creek, an interesting piece manufactured on similar LC fine-grained sandstone is a biface with a plane-convex cross-section $(107.8 \times 66.6$ $\times 29.8 \mathrm{~mm}$ ). As illustrated in Figure 26(a), both faces exhibit a non-patterned flake removal sequence (Callahan, 2010) with flake scars suggesting that they were obtained by applying percussion flaking with some kind of soft or semi-soft percussors (Callahan, 1979). Despite several flakes being detached on its flattest face, the remains of the ventral face of the flake used as a blank are still observable. It is worth mentioning that this kind of artifact is uncommon in the regional archaeological record, although a similar piece from the Saladero site on the Uruguay River shore in Entre Ríos Province, Argentina, was recently reported (Nami, 2016b: Figure 3). On one portion of the convex face, a strong abrasion (Figures 26(b)-(d)) is visible with the naked eye on some flake scars' ridges, some of which are denoted with an arrow in Figure 26(a). Abrasion on the bifaces may owe to different causes, such as final shaping (Disselhoff, 1972: p. 277), surf action (Stanford et al., 2014), bag transportation (Frison \& Bradley, 1980), and the action of the sand resulting from soil movements (Stapert, 1976), 

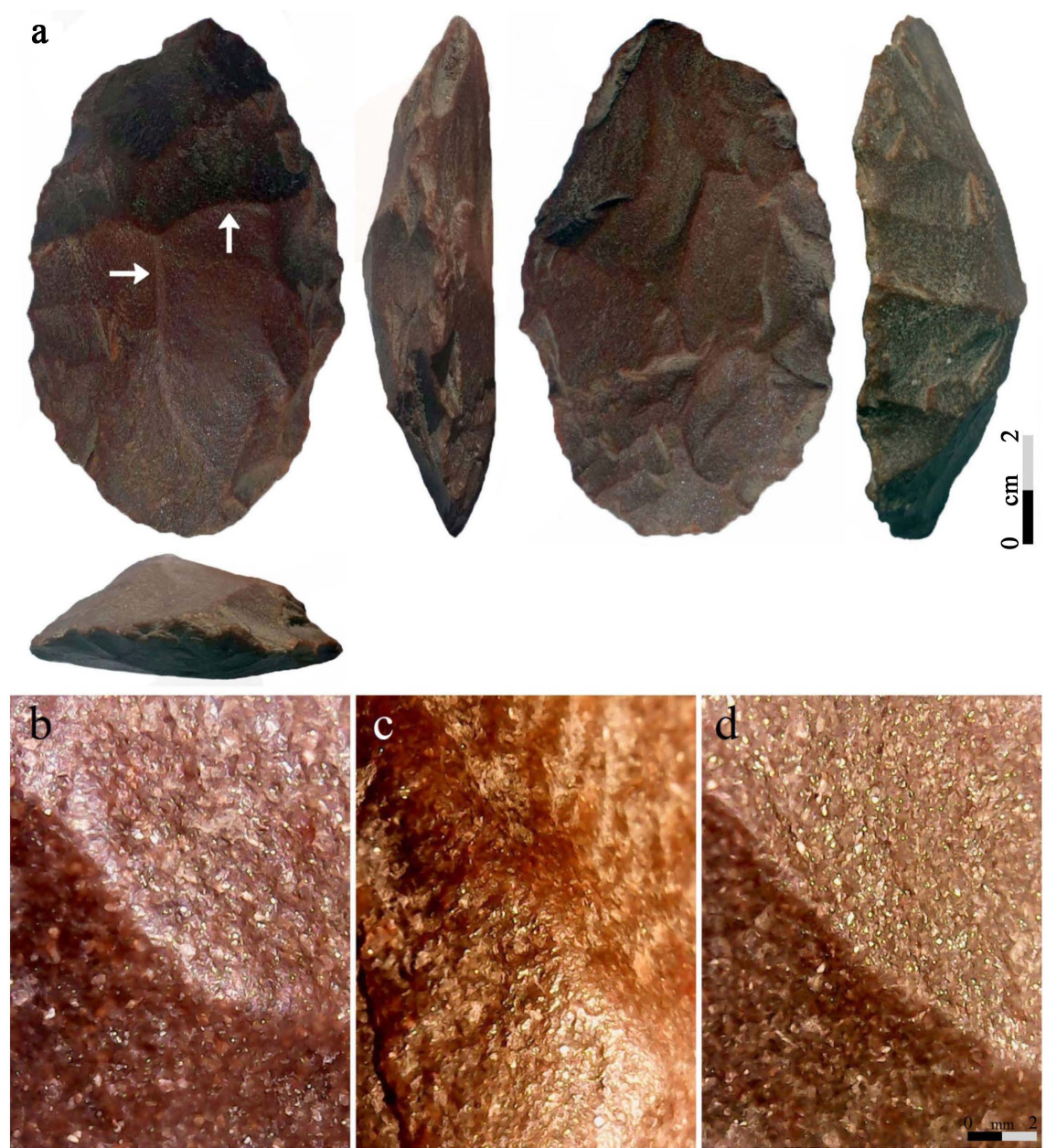

Figure 26. (a) Biface with plane-convex cross-section from El Tala creek. (b) and (c) Microphotographs showing examples of abraded. (b) and (c) and non-abraded ridges (d), denoted with arrows in (a).

among others. Given that it is only present on a few ridges, in the described item the abrasion was probably made by the manufacturers with an unknown aim. As a topic that must be seriously investigated, this sort of artifact might either be a tool or a preform for a kind of instrument with a unifacial edge made on a previously prepared blank, such as has been used in some Late Pleistocene-Early Holocene lithic assemblages in Brazil and Argentina (e.g. Viana Sibeli \& Borges, 2014; Nami \& Civalero, 2017; Civalero \& Nami, 2019).

From an actualistic perspective (Nami, 2018), various experiments were conducted to build a baseline and thus develop an approach to examine diverse regional reduction sequences. Therefore, several replicative experiments were carried out with the FPs (Figure 27), notably the bifacial knives (Figure 28) and the ubiquitous ground/flaked discoid stones (Nami, 2010, 2017c, n.d.b). Of particular importance was an experiment conducted to identify and understand the helical and beveled cross-sections of the common stemmed points (Figure 29 and Figure 30, Nami, 2019c). Found at more than 500 sites (Rodríguez, 2006: p. 144), and distributed in southern Brazil, northeastern Argentina, and all across 

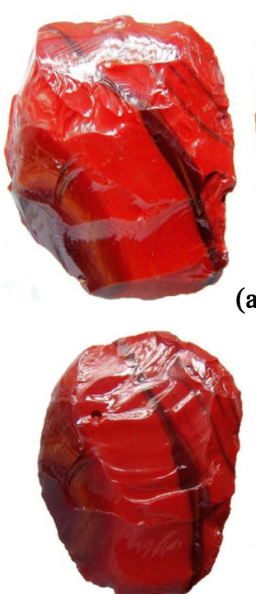

(a)
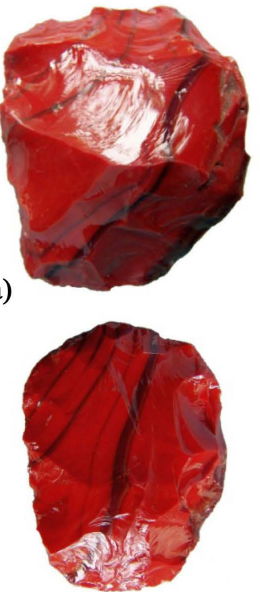

(c)

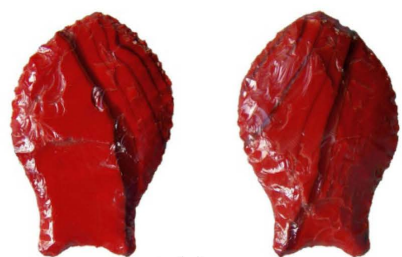

(e)
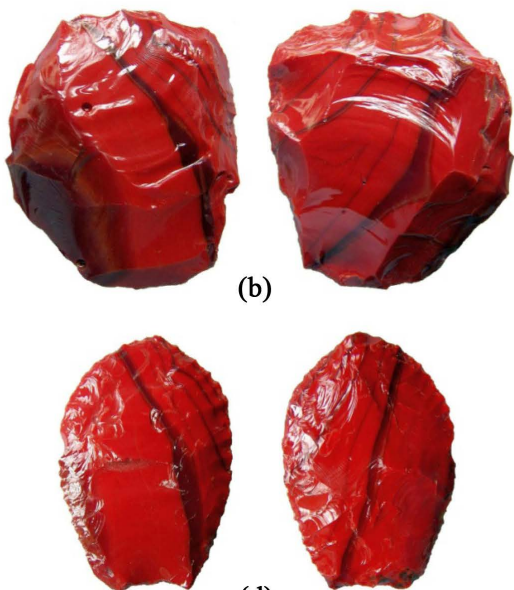

(d)

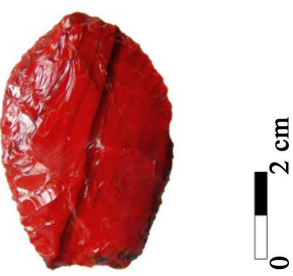

Figure 27. Example of an experimental reduction sequence with bifacial thinning of a FP. ((a)-(e)) Stages 2 to 6 (after Nami, 2010: Plate 19).

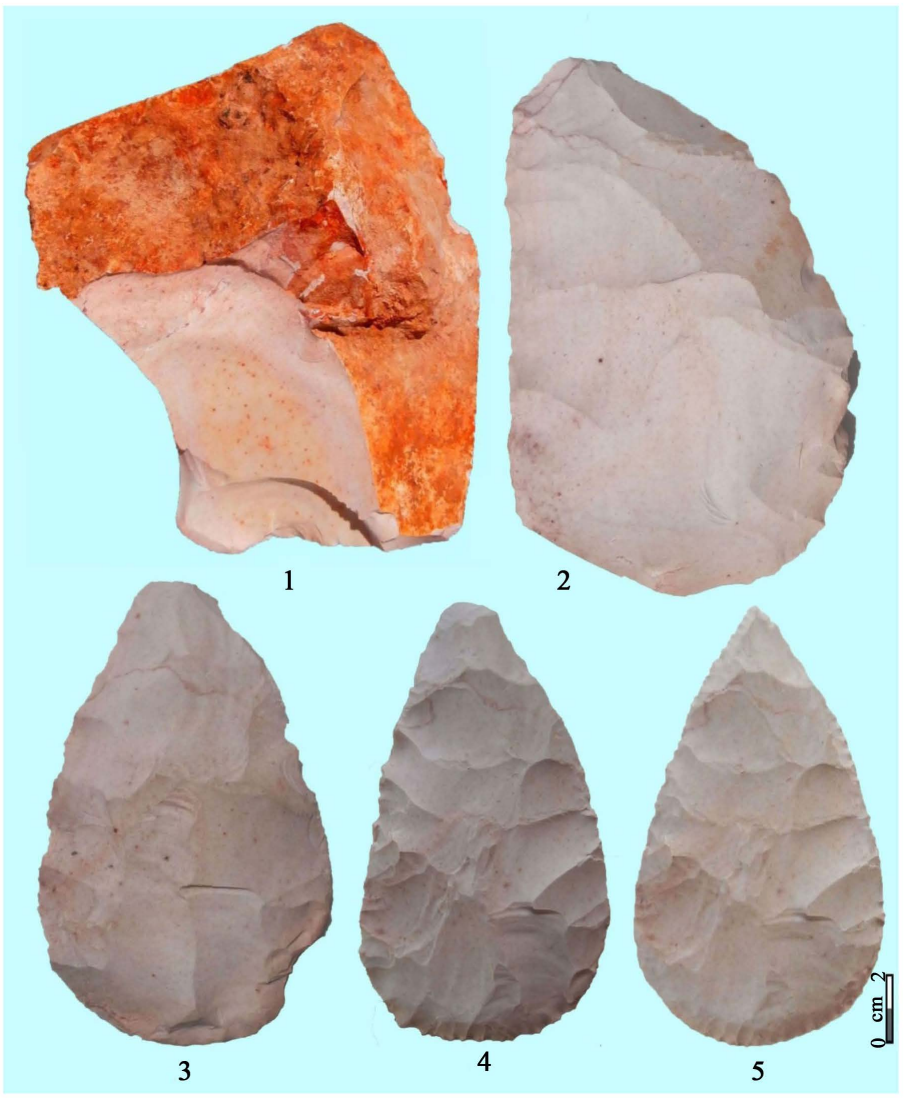

Figure 28. Bifacial reduction of the knives presented in this paper. The numbers indicate the manufacturing stages (after Nami, 2017c: Figure 26). 


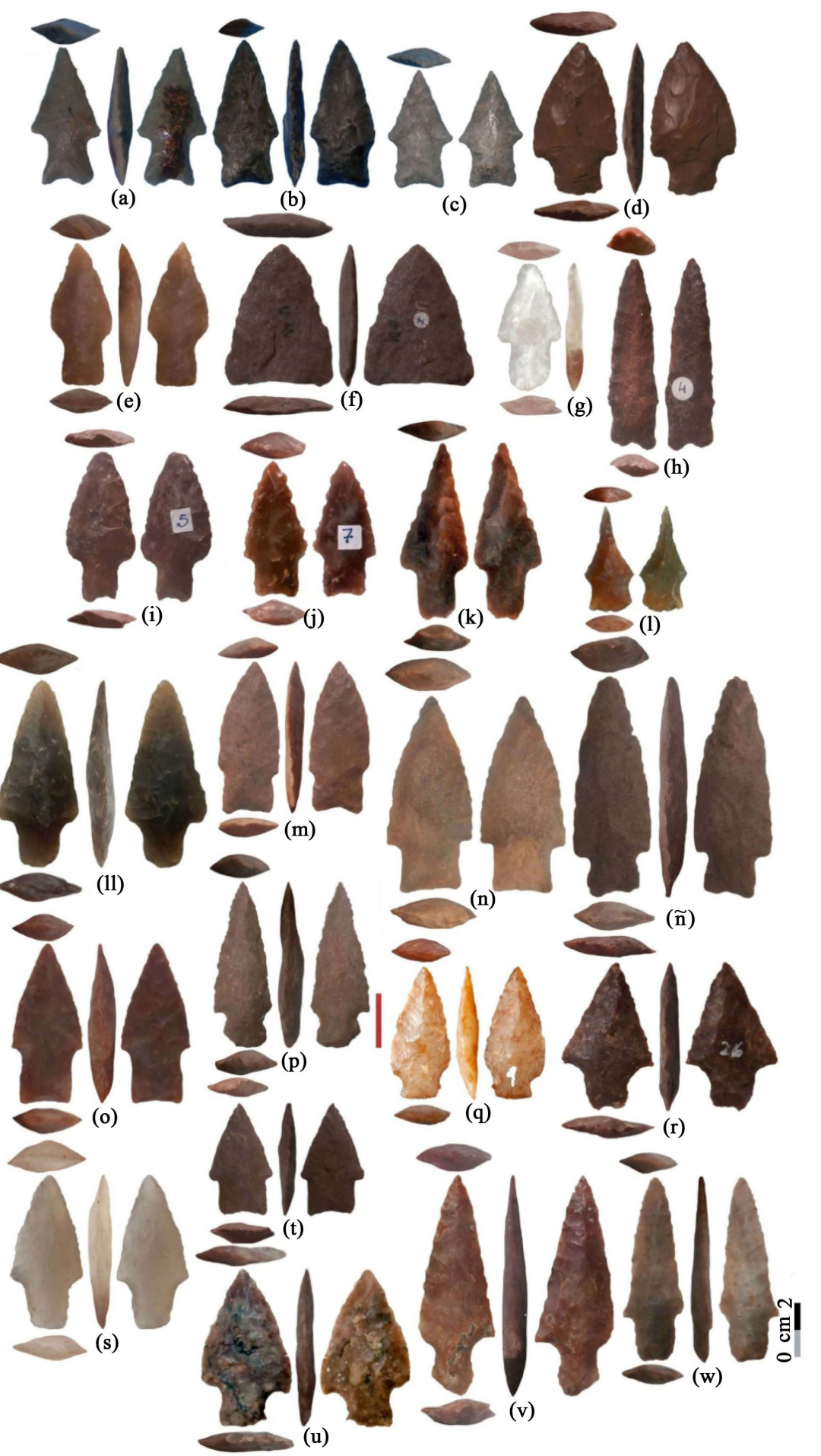

Figure 29. Archaeological exemplars showing the variations of stemmed Umbu-like projectile points with helical and beveled cross-sections from different places in northeastern Argentina and Uruguay (see Nami, 2019c: Table 1).

Uruguay, they are similar to the projectile points that from a traditional perspective broadly characterized the "Umbu tradition", according to Brazilian archaeologists (e.g. Miller, 1969, 1987; Schmitz, 1987). They are currently the topic 


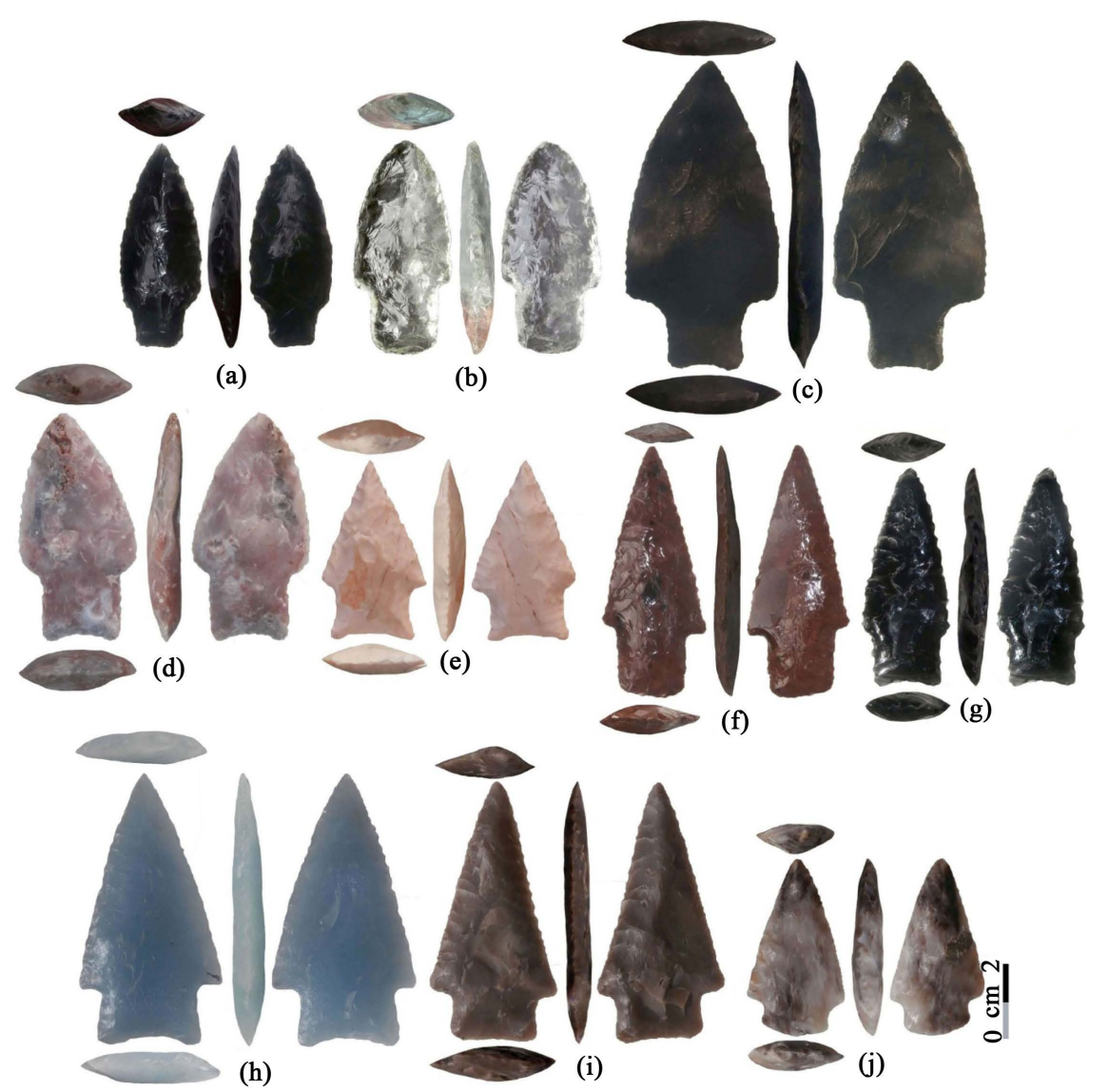

Figure 30. Examples of experimental reproductions of projectile points with beveled and helical cross-sections.

of debate, principally concerning their chronology and morpho-technology, among other issues (e.g. Schmidt Dias, 2007; Suárez, 2017; Moreno da Sousa \& Okumura, 2018; Loponte \& Carbonera, 2019; Moreno da Sousa, 2020). They show a wide range of variations in the shapes of their blades, stems, shoulders, and barbs (Figure 7, Figure 17, Figure 29). However, in many cases they share features in common, such as the aforementioned helical and beveled cross-sections (Figure 29 and Figure 30). Serious and unbiased research considering the lithic assemblages accompanying them, the site formation and geo-archaeological process involved (Feathers \& Nami, 2018), as well as complex deontological issues (Nami, 2011b, 2018), might help to unravel the complicated archeological skein built with these points in some places in the region. In this regard, recent excavations may help to clarify the oldest ages of some variants of such armature tips (Loponte \& Carbonera, 2019).

\section{Discussion and Conclusion}

In summary, this paper has offered a glimpse into the use of diverse scientific disciplines and approaches that may help to deepen various topics concerning the prehistoric past at Tacuarembó. The archaeological excavations as well as the 
variety of dating methods used have allowed us to understand the chronology and certain aspects of the site formation process in the area. LM revealed important depositional gaps and hiatuses of several thousand of years in its sedimentary deposit. The lesson from LM might apply to other sites in the region, where low depositional rates alongside existing unconformities have added to the significant and powerful action of the fluvial erosive process, rendering highly fine-grained archaeological interpretations difficult. Becoming aware of some of these phenomena may facilitate more realistic, unbiased, and objective archaeological interpretations. This is especially relevant when dealing with the remains of the oldest occupations in the region, where mixing with the vestiges of subsequent occupations can make differentiation a challenge. In a nutshell, the AMS and OSL dates at LM showed gaps and unconformities in the sedimentary deposit. This is a fact that might be more common than previously thought, and is especially problematic at sites along river shores (Pouey Vidal, 2018). Besides the above mentioned geo-archaeological issues, adding a new piece of evidence demonstrating that the excavated archaeological sites on the riverbanks (particularly at the more proximate shores) are subjected to a myriad of processes that make archaeological interpretations difficult and doubtful, mainly when the evidence is treated with a biased attitude (see Feathers \& Nami, 2018; Nami, 2018).

This report of new technological investigations has permitted more detailed knowledge to be collected regarding diverse topics related to the reduction systems existing in the area since the terminal Pleistocene. Indeed, the Paleoindian remains add new finds to the record of the early colonizers living in Tacuarembó during the last millennium of the Pleistocene. The FPs from La Fuzarca complement previous finds from Paso de los Novillos (López Mazz, 2017) in the north-central portion of the department, while the reported discoveries from the Negro River basin expand existing knowledge on the shape's variation within such artifacts, additionally confirming that this area is undoubtedly yielding the largest number of FPs in the country (e.g. Bosch et al., 1980; Baeza \& Femenías, 1999; Nami, 2013, among others). In this regard, the new preforms and finished products append further data on barely known FPs' reduction sequences-mainly those whose bases were fluted-as well as to the morphological variations existing in the final manufactured goods. The identification of clear turtle-back Levallois-like cores at LC agrees with earlier finds in other locations in southeastern South America, which were previously identified in the Misiones Province in northeastern Argentina (Nami, 1995b), and particularly in Uruguay at the Negro River (Nami, 2013: Figures 8(a)-(d)). However, LC yielded excellent examples of the employment of the flaking strategy by the prehistoric populations living in Tacuarembó. From the experimental lithic technology perspective, modern reproductions of the stone tools afforded an understanding of various aspects of the reduction sequences and technical features of their analogs from the past. 


\section{Acknowledgements}

I am indebted to: the University of Buenos Aires and CONICET for their continuous support; the Museo Nacional de Antropología de Uruguay for sponsoring my archaeological research in that country; A. Toscano, former Director of the Museo Nacional de Antropología, for his constant support and help; A. Florines, for his constant support, help, and advice regarding different aspects of this research; C. Arezo Posada, Director of the Dirección General de Educación y Cultura in Tacuarembó city, for allowing me to access and study the lithic collections curated at the Museo del Indio y del Gaucho Washington Escobar; S. A. Muga Prieto (R.I.P.) and the authorities of the Museo Histórico Casa Muga, San Gregorio de Polanco village, for their permission to document some of the artifacts depicted in this paper; R. Cáceres, A. Castillo, and F. Moreira, for their invaluable help concerning different aspects of my research in northern Tacuarembó, and for their kindness in allowing me to study their collections; R. Bianchi from Dolores city, for his permission to study his collection and for providing me with useful information; and M. Cuadrado, G. D. Nami and L. A. Nami, for their continuous help in various parts of the field and laboratory research. Particular thanks go to A. Castillo and R. Cáceres for their continuous data input, kindness, and generosity during my stay in Tacuarembó city.

\section{Conflicts of Interest}

The author declares no conflicts of interest regarding the publication of this paper.

\section{References}

A.C.R.T. (n.d.). Atlas de la cuenca del río Tacuarembó. Ministerio de Vivienda Ordenamiento Territorial y Medio Ambiente-MVOTMA, Dirección Nacional de Ordenamiento Territorial (DINOT) del Ministerio de Vivienda, Ordenamiento Territorial y Medio Ambiente (MVOTMA) Montevideo.

Baeza, J., \& Femenías, J. (1999). Nuevas observaciones sobre puntas colas de pescado. Paper presented at the First Conference on Pampean Archaeology, Venado Tuerto.

Baeza, J., Femenías, J., Suárez, R., \& Florines, A. (2001). Investigación arqueológica en el río negro medio (Informe preliminar). In Arqueología uruguaya hacia el fin del milenio (X Congreso Nacional de Arqueología, Colonia del Sacramento, 16-19 de junio, 1997) (pp. 285-295). Montevideo: Asociación Uruguaya de Arqueología.

Behling, H., Arz, H. W., Patzold, J., \& Wefer, G. (2002). Late Quarternary Vegetational and Climate Dynamics in Southeastern Brazil, Inferences from Marine Cores GeoB 3229-2 and GeoB 3202-1. Paleogregraphy, Paleoclimatology, Paleoecology, 179, 227-243. https://doi.org/10.1016/S0031-0182(01)00435-7

Bell, R. E. (1965). Investigaciones arqueológicas en el sitio de El Inga, Ecuador. Quito: Casa de Cultura Ecuatoriana.

Binford, L. R. (1986). An Alyawara Day: Making Men's Knives and beyond. American Antiquity, 51, 547-562. https://doi.org/10.2307/281751

Bird, J. (1938). Before Magellan. Natural History, 16, 16-28.

Bird, J. (1946). The archaeology of Patagonia. In J. H. Steward (Ed.), Handbook of South 
American Indians: Vol. 1 The Marginal Tribes (pp. 17-29). Washington DC: Smithsonian Institution Bureau of American Ethnology, Bulletin 143.

Bórmida, M. (1968). Arqueología de las altas cotas de la costa nordpatagónica. Actas del Congreso Internacional de Americanistas, 37, 345-374.

Bosch, A., Femenías, J., \& Olivera, J. (1980). Dispersión de las puntas de proyectil líticas pisciformes en el Uruguay. In Anales, III Congreso Nacional de Arqueología (1974). Montevideo: Centro de Estudios Arqueológicos.

Bossi, J., \& Navarrro, R. (1998). Geología del Uruguay. Montevideo: Universidad de la República.

Bronk Ramsey, C., \& Lee, S. (2013). Recent and Planned Developments of the Program OxCal. Radiocarbon, 55, 720-730. https://doi.org/10.1017/S0033822200057878

Burley, D. V. (2005). Mid-Sequence Archaeology at the Sigatoka Sand Dunes with Interpretive Implications for Fijian and Oceanic Culture History. Asian Perspectives, 44, 320-348. https://doi.org/10.1353/asi.2005.0019

Callahan, E. (1979). The Basics of Biface Knapping in the Eastern Fluted Point Tradition. A Manual for Flintknappers and Lithic Analysts. Archaeology of Eastern North America, $7,1-180$.

Callahan, E. (2010). Flake Removal Sequence and Cultural Inference. A Solutrean Perspective. In H. G. Nami (Ed.), Experiments and Interpretation of Traditional Technologies: Essays in Honor of Errett Callahan (pp. 561-659). Buenos Aires: Ediciones de Arqueología Contemporánea.

Civalero, M. T., \& Nami, H. G. (2019). Experimentos y esquemas diacríticos para explorar técnicas de talla unifacial del Holoceno temprano en el noroeste de Santa Cruz. Revista del Museo de Antropología, 12.

Cordero, S. (1960). Los charrúas. Montevideo: Editorial Mentor.

da Silva, J. (1970). Aspectos de la geografía física. In D. Auanati, M. Benedetto, \& W. Perdomo (Eds.), Los departamentos. Tacuarembó (pp. 11-15). Montevideo: Editorial Nuestra Tierra.

del Castillo Laborde, L. (2008). The Rio de la Plata River Basin: The Path towards Basin Institutions. In O. Varis, C. Tortajada, \& A. K. Biswas (Eds.), Management of Transboundary Rivers and Lakes. Water Resources Development and Management (pp. 269-292). Berlin-Heidelberg: Springer. https://doi.org/10.1007/978-3-540-74928-8_11

Disselhoff, H. D. (1972). Das Imperium der Inka und die indianischen Frühkulturen der Andenländer: Von den Jahrtausende alten Felsbilden bis zu den andinen Hochkulturen Südamerikas. Berlin: Safari-Verlag.

Dott, R. H. J. (1983). Episodic Sedimentation-How Normal Is Average? How Rare Is Rare? Does It Matter? Journal of Sedimentary Petrology, 53, 5-23. https://doi.org/10.1306/212F8148-2B24-11D7-8648000102C1865D

E.G.d.U. (2019). Enciclopedia geográfica del Uruguay. http://www.montevideo.com.uy/enciclopedia/cuchilla.htm

Ericson, J. A., \& Purdy, B. (1984). Toward the Analysis of Lithic Production Systems. In J. Ericson, \& B. Purdy (Eds.), Prehistoric Quarries and Lithic Production (pp. 1-9). Cambridge: Cambridge University Press. https://doi.org/10.1017/CBO9780511753244.002

Feathers, J. K., \& Nami, H. G. (2018). Luminescence Dating of Sediments from Two Sites in the Middle Negro River Basin, Central Uruguay. Latin American Antiquity, 29, 495-513. https://doi.org/10.1017/laq.2018.9

Femenías, J., Nami, H. G., Florines, A., \& Toscano, A. (2011). GIS Archaeological Site Record and Remarks on Paleoindian Finds in the Rio Negro River Basin, Central Uruguay. Current Research in the Pleistocene, 28, 98-101. 
Figueira, J. H. (1892). Los primitivos habitantes del Uruguay. In El Uruguay en la exposición histórica americana de Madrid (pp. 121-219). Montevideo: Imprenta Artística Americana de Dornaleche y Reyes.

Flegenheimer, N., Miotti, L., \& Mazzia, N. (2014). Rethinking Early Objects and Landscapes in the Southern Cone: Fishtail-Point concentrations in the Pampas and Northern Patagonia. In K. E. Graf, C. V. Ketron, \& M. R. Waters (Eds.), Paleoamerican Odyssey (pp. 359-376). College Station: Texas A\&M University Press.

Frison, G. C., \& Bradley, B. (1980). Folsom Tools and Technology at the Hanson Site, Wyoming. Albuquerque: University of New Mexico Press.

Gianotti, C. (2005). Inventario del Patrimonio Arqueológico Monumental del Valle del Yaguarí. In C. G. García (Ed.), Proyecto de Cooperación Científica: Desarrollo metodológico y aplicación de nuevas tecnologías para la gestión integral del Patrimonio Arqueológico en Uruguay (pp. 27-47), Galicia: Traballos de Arqueoloxía e Patrimonio, CSIC-XUGA, Instituto de Estudios Gallegos Padre Sarmiento (IEGPS).

Gianotti, C., del Puerto, L., Inda, H., \& Capdepont, I. (2013). Construir para producir. pequeñas elevaciones en tierra para el cultivo de maíz en el sitio Cañada de los Caponcitos, Tacuarembó (Uruguay). Cuadernos del Instituto Nacional de Antropología y Pensamiento Latinoamericano-Series Especiales, 1, 12-25.

Gurarii, G. Z. (2005). Geomagnetic Field Reversals: Main Results and Basic Problems. Russian Journal of Earth Sciences, 7, ES3003. https://doi.org/10.2205/2005ES000175

Herz, N., \& Garrison, E. G. (1998). Geological Methods for Archaeology. New York: Oxford University Press.

Hester, T. R., \&, Heizer, R. F. (1972). Problems in the Functional Interpretation of Artifacts: Scraper Planes from Mitla and Yagul, Oaxaca. Contributions of the University of California Archaeological Research Facility, 14, 107-123.

Hoffman, K. A., \& Singer, B. S. (2004). Regionally Recurrent Paleomagnetic Transitional Fields and Mantle Processes. In J. E. E. Channell, D. V. Kent, W. Lowrie, \& J. G. Meert (Eds.), Timescales of the Paleomagnetic Field (pp. 233-43). Washington DC: AGU. https://doi.org/10.1029/145GM17

Hogg, A. G., Quan, H., Blackwell, P. G., Mu, N., Buck, C. E., Guilderson, T. P., Heaton, T. J., Palmer, J. G., Reimer, P. J., Reimer, R. W., Turney, C. S., \& Zimmerman, S. R. H. (2013). SHCal13 Southern Hemisphere Calibration, 0-50,000 Years cal BP. Radiocarbon, 55, 1889-1903. https://doi.org/10.2458/azu_js_rc.55.16783

Holliday, V. T. (1985). Archaeological Geology of the Lubbock Lake Site, Southern Highplains of Texas. Geological Society of America Bulletin, 96, 1483-1492. https://doi.org/10.1130/0016-7606(1985)96<1483:AGOTLL >2.0.CO;2

Iriarte, J. (2006). Vegetation and Climate Change Since 14,810 14C yr B.P. in Southeastern Uruguay and Implications for the Rise of Early Formative Societies. Quaternary Research, 65, 20-32. https://doi.org/10.1016/j.yqres.2005.05.005

Jodry, M. A. (1999). Folsom Technological and Socioeconomic Strategies: Views from Stewart's Cattle Guard and the Upper Rio Grande Basin, Colorado. PhD Dissertation, Washington DC: American University.

Kandel, A., \& Conard, N. (2013). Stone Age Economics and Land Use in the Geelbek Dunes. In A. Jerardino, A. Malan, \& D. Braun (Eds.), The Archaeology of the West Coast of South Africa (pp. 24-49). Oxford: BAR International Series 2526, Archaeopress Publishers of British Archaeological Reports.

Karavanić, I., Miracle, P. T., Culiberg, M., Kurtanjek, D., Zupanič, J., Golubić, V., Paunović, M., Lenardić, J. M., Malez, V., Šošić, R., Janković, I., \& Smith, F. H. (2008). The Middle Paleolithic from Mujina Pećina, Dalmatia, Croatia. Journal of Field Archaeology, 33, 259-277. https://doi.org/10.1179/009346908791071259 
Laj, C., \& Channell, J. E. T. (2007). Geomagnetic Excursions. In G. Schubert (Ed.), Treatise of Geophysics (Vol. 5, pp. 373-416). Oxford: Elsevier. https://doi.org/10.1016/B978-044452748-6.00095-X

López Mazz, J. (2017). Silcrete Procurement System in Uruguayan Prehistory. Journal of Archaeological Science: Reports, 15, 561-569. https://doi.org/10.1016/j.jasrep.2017.08.009

López Mazz, J., Gascue Amaral, A., \& Moreno Rudolph, F. (2003-2004). La prehistoria del este de Uruguay: Cambio cultural y aspectos ambientales. Anales de Prehistoria y Arqueología, 19-20, 9-24.

Loponte, D., \& Carbonera, M. (2019). El sitio arqueológico Otto Aigner 1. Una ocupación del Holoceno temprano en el Alto río Uruguay. Paper presented at the IX Simposio Internacional El Hombre Temprano en América, Necochea, Argentina, 27-30 November 2019.

Loponte, D., Carbonera, M., \& Silvestre, R. (2015). Fishtail Projectile Points from South America: The Brazilian Record. Archaeological Discovery, 3, 85-103. https://doi.org/10.4236/ad.2015.33009

Loponte, D., Okumura, M., \& Carbonera, M. (2016). New Records of Fishtail Projectile Points from Brazil and Its Implications for Its Peopling. Journal of Lithic Studies, 3, 63-85. https://doi.org/10.2218/jls.v3i1.1312

Lourdeau, A., Carbonera, M., Hoeltz, S., Pereira Santos, M. C., de Oliveira, L., Amélie Da Costa, L., \& Viana, S. (2017). Blade debitage in Southern Brazil: We Have Cores! [Debitagem laminar no Sul do Brasil: Habemus nucleos!]. Journal of Lithic Studies, 4, 127-143. https://doi.org/10.2218/jls.v4i3.2530

Luedtke, B. (1979). The Identification of Sources of Chert Artifacts. American Antiquity, 44, 744-757. https://doi.org/10.2307/279116

Luedtke, B. (1994). An Archaeologist's Guide to Chert and Flint. Los Angeles: Institute of Archaeology, University of California.

Martinez, S., \& Ubilla, M. (2004). El cuaternario en Uruguay. In Cuencas sedimentarias de Uruguay: Cenozoico (pp. 195-227). Montevideo: DIRAC, Facultad de Ciencias.

Maruca Sosa, R. (1957). La Nación Charrúa. Montevideo: Ediciones Letras.

Merrill, R. T., \& McFadden, P. L. (2005). The Use of Magnetic Field Excursions in Stratigraphy. Quaternary Research, 63, 232-237. https://doi.org/10.1016/j.yqres.2005.02.007

Miller, E. T. (1969). Resultados preliminares das escavaçōes no sítio pré-cerâmico RS-LN-1: Cerrito Dalpiaz (abrigo-sobrocha). Iheringia, 1, 43-112.

Miller, E. T. (1987). Pesquisas Arqueológiocas Paleoindigenas no Brasil Ocdidental. Estudios Atacameños, 8, 37-61. https://doi.org/10.22199/S07181043.1987.0008.00005

Moreno da Sousa, J. C. (2020). The Technological Diversity of Lithic Industries in Eastern South America during the Late Pleistocene-Holocene Transition. In Pleistocene Archaeology-Migration, Technology, and Adaptation. https://doi.org/10.5772/intechopen.89154

Moreno da Sousa, J. C., \& Okumura, M. (2018). The Association of Palaeoindian Sites from Southern Brazil and Uruguay with the Umbu Tradition: Comments on Suarez et al. (2017). Quaternary International, 467, 292-296. https://doi.org/10.1016/j.quaint.2017.11.056

Moro, R. S., de Mattos Bicudo, C. E., de Melo, M. S., \& Schmitt, J. (2004). Paleoclimate of the Late Pleistocene and Holocene at Lagoa Dourada, Paraná State, Southern Brazil. Quaternary International, 114, 87-99. https://doi.org/10.1016/S1040-6182(03)00044-2 
Nami, H. G. (1992). Noticia sobre la existencia de técnica "Levallois" en Península Mitre, extremo sudoriental de Tierra del Fuego. Anales del Instituto de la Patagonia, 21, 73-80.

Nami, H. G. (1995a). Holocene Geomagnetic Excursion at Mylodon Cave, Ultima Esperanza, Chile. Journal of Geomagnetism and Geoelectricity, 47, 1325-1332.

https://doi.org/10.5636/jgg.47.1325

Nami, H. G. (1995b). Nota sobre la presencia de núcleos preparados y lascas predeterminadas en Puerto Esperanza (Misiones, Argentina). Cuadernos del Instituto Nacional de Antropología y Pensamiento Latinoamericano, 16, 357-365.

Nami, H. G. (1999). Possible Holocene Excursion of the Earth's Magnetic Field in Southern South America: New Records from Archaeological Sites in Argentina. Earth, Planets and Space, 51, 175-191. https://doi.org/10.1186/BF03352222

Nami, H. G. (2001a). New Data on Fell Lithic Technology from Paso del Puerto, Río Negro Basin, Uruguay. Current Research in the Pleistocene, 18, 47-50.

Nami, H. G. (2001b). Consideraciones tecnológicas preliminares sobre los artefactos líticos de Cerro de los Burros (Maldonado, Uruguay). Comunicaciones Antropológicas de los Museos Nacionales de Historia Natural y Antropología de Montevideo, 3, 1.

Nami, H. G. (2006a). Preliminary Paleomagnetic Results of a Terminal Pleistocene/Holocene Record from Northeastern Buenos Aires Province (Argentina). Geofizika, 23, 119-141.

Nami, H. G. (2006b). Experiments to Explore the Paleoindian Flake-Core Technology in Southern Patagonia. In J. Apel, \& K. Knutsson (Eds.), Skilled Production and Social Reproduction. Aspects on Traditional Stone Tool Technologies (pp. 69-80). Uppsala: Uppsala University, Societas Archaeologica Upsaliensis (SAU) \& the Department of Archaeology and Ancient History.

Nami, H. G. (2007). Research in the Middle Negro River Basin (Uruguay) and the Paleoindian Occupation of the Southern Cone. Current Anthropology, 48, 164-176. https://doi.org/10.1086/510465

Nami, H. G. (2008). Paleomagnetic Results from the Urupez Paleoindian Site, Maldonado Department, Uruguay. Current Research in the Pleistocene, 25, 40-43.

Nami, H. G. (2009). Crystal Quartz and Fishtail Projectile Points: Considerations on Raw Materials Selection by Paleo-Southamericans. Current Research in the Pleistocene, 26, 9-12.

Nami, H. G. (2010). Tecnología Paleoindia de Sudamérica: Nuevos experimentos y observaciones para conocer la secuencia de reducción Fell. Orígenes, 9, 1-40.

Nami, H. G. (2011a). New Detailed Paleosecular Variation Record at Santa Lucía Archaeological Site (Corrientes Province, Northeastern Argentina). Geofísica Internacional, 50, 9-21.

Nami, H. G. (2011b). Fundamentos teóricos y epistemológicos sobre arqueologia y tecnología lítica experimental. Arqueología Rosarina Hoy, 3, 75-98.

Nami, H. G. (2012). New Detailed Holocene Paleomagnetic Records with Anomalous Geomagnetic Field Bahavior in Argentina. Geoacta, 37, 83-116.

Nami, H. G. (2013). Archaelogy, Paleoindian Research and Lithic Technology in the Middle Negro River, Central Uruguay. Archaeological Discovery, 1, 1-22. https://doi.org/10.4236/ad.2013.11001

Nami, H. G. (2014a). Arqueología del último milenio del Pleistoceno en el Cono Sur de Sudamérica, puntas de proyectil y observaciones sobre tecnología Paleoindia en el Nuevo Mundo. In M. Farias, \& A. Lourdeau (Eds.), Peuplement et Modalités d'Occupation de l'Amérique du Sud: L'Apport de la Technologie Lithique (pp. 279-336). Prigonrieux: @rchéo-éditions.com. 
Nami, H. G. (2014b). Secuencias de Reducción Bifaciales Paleoindias y Puntas Fell en el Valle del Ilaló (Ecuador): Observaciones para Comprender la Tecnología Lítica Pleistocénica en Sudamérica. In M. Farias, \& A. Lourdeau (Eds.), Peuplement et Modalités d'Occupation de l'Amérique du Sud: L'Apport de la Technologie Lithique (pp. 179-220). Prigonrieux: @rchéo-éditions.com.

Nami, H. G. (2015a). Experimental Observations on Some Non-Optimal Materials from Southern South America. Lithic Technology, 40, 128-146.

https://doi.org/10.1179/2051618515Y.0000000004

Nami, H. G. (2015b). New Paleomagnetic Results and Evidence for a Geomagnetic Field Excursion during the Pleistocene-Holocene Transition at Pichincha Province, Ecuador. Geofísica Internacional, 54, 127-148. https://doi.org/10.1016/j.gi.2015.04.009

Nami, H. G. (2016a). Paleo American Finds from Venezuela: Evidence to Discuss the Spread of Fell Points and the Peopling of Northern South America. Cadernos do Ceom, Acervos para História da Educação, 29, 121-128. https://doi.org/10.22562/2016.45.08

Nami, H. G. (2016b). Artefactos bifaciales del sudeste de Corrientes y nordeste de Entre Ríos: Un estudio tecnológico. Revista de Antropología del Museo de Entre Ríos, 2, 77-87.

Nami, H. G. (2017a). Silcrete as a Valuable Resource for Stone Tool Manufacture and Its Use by Paleo-American Hunter-Gatherers in Southeastern South America. Journal of Archaeological Science: Reports, 15, 539-560. https://doi.org/10.1016/j.jasrep.2016.05.003

Nami, H. G. (2017b). Hallazgos Paleoindios en Dolores, departamento de Soriano, Uruguay. Cuadernos del Instituto Nacional de Antropología y Pensamiento Latinoamericano, 26, 77-83.

Nami, H. G. (2017c). Exploring the Manufacture of Bifacial Stone Tools from the Middle Rio Negro Basin, Uruguay: An Experimental Approach. Ethnoarchaeology: Journal of Archaeological, Ethnographic and Experimental Studies, 9, 53-80. https://doi.org/10.1080/19442890.2017.1286757

Nami, H. G. (2018). Theoretical and Epistemological Thoughts on Archaeology and Experimental Lithic Technology. Journal of Research in Philosophy and History, 1, 139-165. https://doi.org/10.22158/jrph.v1n2p139

Nami, H. G. (2019a). Paleoamerican Occupation, Stone Tools from the Cueva del Medio, and Considerations for the Late Pleistocene Archaeology in Southern South America. Quaternary, 2, 28. https://doi.org/10.3390/quat2030028

Nami, H. G. (2019b). Paleomagnetic Results from Archaeological Sites in Argentinean Patagonia: Evidence for the Holocene Geomagnetic Excursions in Southern South America and Its Chronostratigraphic Implications. Archaeological Discovery, 7, 127-154. https://doi.org/10.4236/ad.2019.72008

Nami, H. G. (2019c). Consideraciones sobre la reproducción experimental de secciones helicoidales y filos asimétricos alternos en puntas de proyectil del sudeste de Sudamérica. Cuadernos del Instituto Nacional de Antropología y Pensamiento Latinoamericano, 28, 64-87.

Nami, H. G. (n.d.a). Paleomagnetism on Holocene Sedimentary Deposits and Anomalous Paleosecular Variations Records in del Plata Basin, Southeastern South America.

Nami, H. G. (n.d.b). Assessing the Manufacturing Sequence of Unusual Ground Discoid Biconvex Stones from Southeastern South America: An Experimental Research.

Nami, H. G., \& Castro, A. (2010). New Paleoindian Finds and Micro-Wear Analysis at Arroyo Cacique Site, Tacuarembó Department, Uruguay. Current Research in the Pleistocene, 27, 25-28. 
Nami, H. G., \& Castro, A. (2014). Fishtail Points, Technology and Microwear Analysis from the Negro River Basin, Uruguay. Archaeological Discovery, 2, 65-70. https://doi.org/10.4236/ad.2014.23008

Nami, H. G., \& Civalero, M. T. (2017). Distinctive Unifacial Technology during the Early Holocene in Southern South America. Archaeological Discovery, 5, 101-115. https://doi.org/10.4236/ad.2017.53007

Nami, H. G., \& Yataco Capcha, J. (2020). Further Data on Fell Points from the Southern Cone of South America. MS.

Nami, H. G., de la Peña, P., Vásquez, C., Feathers, J., \& Wurz, S. (2016). Paleomagnetic Results and New Dates from Late Pleistocene and Holocene Deposits from Klasies River Cave 1, South Africa. South African Journal of Science, 112, Article No. 2016-0051. https://doi.org/10.17159/sajs.2016/20160051

Nami, H. G., Vásquez, C. A., \& Durán, V. A. (2017). Detailed Early Holocene (10.3 cal kybp) Paleomagnetic Record with Anomalous Directions from Mendoza Province, Western Argentina. Latinmag Letters, 7, LL17-0702Rs.

Nami, H. G., Vásquez, C. A., Wadley, L., \& de la Peña, P. (2020). Detailed Paleomagnetic Record at Rose Cottage Cave, South Africa: Implications for the Holocene Geomagnetic Field Behavior and Chronostratigraphy. South African Journal of Science, 116, Article No. 6550. https://doi.org/10.17159/sajs.2020/6550

Nichols, G. W. (1970). The Reverse Hinge Fracture Problem in Fluted Point. Manufacture. Missouri Archaeological Society, Memoir, 8, 1-10.

Nikzad, M., Sedighian, H., \& Ghasemi, E. (2015). New Evidence of Palaeolithic Activity from South Khorasan, Eastern Iran. Antiquity, 89.

https://www.antiquity.ac.uk/projgall/nikzad347

Okumura, M., \& Araujo, A. G. M. (2014). Long-Term Cultural Stability in Hunter-Gatherers: A Case Study Using Traditional and Geometric Morphometric Analysis of Lithic Stemmed Bifacial Points from Southern Brazil. Journal of Archaeological Science, 45, 59-71. https://doi.org/10.1016/j.jas.2014.02.009

Panario, D., \& Gutiérrez, O. (1999). The Continental Uruguayan Cenozoic: An Overview. Quaternary International, 62, 75-84. https://doi.org/10.1016/S1040-6182(99)00025-7

Pouey Vidal, V. (2018). La Ocupación Cazadora-Recolectora durante la Transición Pleistoceno-Holoceno en el Oeste de Rio Grande do Sul-Brasil: Geoarqueología de los Sitios en la Formación Sedimentaria Touro Passo. Oxford: Archaeopress Publishing Ltd. https://doi.org/10.24885/sab.v32i1.578

Praderi, R. C., Vivo, J. E. \& Vázquez Praderi, F. (2006). Ríos, Lagos y Montes Indígenas del Uruguay. Montevideo: Ediciones de la Plaza.

Reimer, P. J, Brown, T. A., \& Reimer, R. W. (2004a). Discussion: Reporting and Calibration of Post-Bomb 14C Data. Radiocarbon, 46, 1334.

https://doi.org/10.1017/S0033822200033154

Reimer, P. J., Brown, T. A., \& Reimer, R. W. (2004b). Discussion: Reporting and Calibration of Post-Bomb 14C Data. Radiocarbon, 46, 1299-1304. https://doi.org/10.1017/S0033822200033154

Rodríguez, J. A. (1998). Esquemas de integración cultural y síntesis en la arqueología del noreste argentino. In A. R. G. Homenaje (Ed.), 50 anos de aportes al desarrollo y consolidación de la antropología argentina (pp. 121-153). Buenos Aires: Fundación Argentina de Antropología y Facultad de Filosofía y Letras.

Rodríguez, J. A. (2001). Nordeste prehispánico. In E. E. Berberián, A. E. Nielsen, \& M. E. Albeck (Eds.), Historia argentina prehispánica, Volume II (pp. 693-736). Córdoba: Brujas. 
Rodríguez, J. A. (2006). El poblamiento y el proceso de la secuencia cultural prehistórica de la Cuenca del Plata. Folia Histórica del Nordeste, 16, 139-159.

https://doi.org/10.30972/fhn.0163426

Ruiz Pessenda, L. C., Marques Gouveia, S. E., \& Aravena, R. (2001). Radiocarbon Dating of Total Soil Organic Matter and Humin Fraction and Its Comparison with 14C Ages of Fossil Charcoal. Radiocarbon, 43, 595-601. https://doi.org/10.1017/S0033822200041242

Scharpenseel, H. W., \& Schiffmann, H. (1977). Soil Radiocarbon Analysis and Soil Dating. Surveys in Geophysics, 3, 143-156. https://doi.org/10.1007/BF01449190

Schmidt Dias, A. (2007). Da Tipologia à Tecnologia: Reflexões sobre das Indústrias Líticas da Tradição Umbu. In L. Bueno, \& A. Isnardis (Eds.), Das Pedras aos Homens: Tecnologia Lítica na Arqueologia Brasileira (pp. 33-66). Belo Horizonte: Argentum Editora.

Schmitz, P. I. (1987). Prehistoric Hunters and Gatherers of Brazil. Journal of World Prehistory, 1, 53-126. https://doi.org/10.1007/BF00974817

Stanford, D., Lowery, D., Jodry, M., Bradley, B. A., Kay, M., Stafford, T. W., \& Speakman, R. J. (2014). New Evidence for a Possible Paleolithic Occupation of the Eastern North American Continental Shelf at the Last Glacial Maximum. In A. M. Evans, J. C. Flatman, \& N. C. Flemming (Eds.), Prehistoric Archaeology on the Continental Shelf. New York: Springer. https://doi.org/10.1007/978-1-4614-9635-9_5

Stapert, D. (1976). Some Natural Surface Modifications on Flint in the Netherlands. Palaeohistoria, XVVIIII, 8-41.

Stein, J. K. (1992). Organic Matter in Arcaheological Contexts. In V. T. Holliday (Ed.), Soils in Archaeology (pp. 193-216). Washington DC: Smithsonian Institution Press.

Suárez, R. (2017). The Human Colonization of the Southeast Plains of South America: Climatic Conditions, Technological Innovations and the Peopling of Uruguay and South of Brazil. Quaternary International, 431, 181-193.

https://doi.org/10.1016/j.quaint.2016.02.018

Suárez, R., \& Leigh, D. S. (2010). Tres Árboles Site (RN2-2b): A Buried Late Pleistocene Fishtail Site in Alluvium, Central Uruguay. Current Research in the Pleistocene, 27, 31-33.

Taddei, A. (1969). Un yacimiento de cazadores superiores del medio río Negro, Uruguay. Pesquisas. Antropología, 20, 57-78.

Taddei, A. (1977). Las Industrias Líticas Arqueológicas de los Ríos Tacuarembó Grande y Chico. In V Encuentro de Arqueología del Litoral (pp. 225-243). Fray Bentos: MEC-IMR.

Taddei, A. (1980). Un yacimiento de cazadores superiores en el Río Negro (Paso del Puerto) (Uruguay). In III Congreso Nacional de Arqueología (1974). Anales. Montevideo: CEA.

Taddei, A. (1985). El Río Negro Medio. Estado Actual de las Investigaciones Arqueológicas en Uruguay (parte 1) 3, 35-42. Montevideo: CEA.

Taddei, A. (1987). Algunos aspectos de la arqueología prehistórica del Uruguay. Estudios Atacameños, 8, 62-93. https://doi.org/10.22199/S07181043.1987.0008.00006

Tarling, D. (1983). Palaeomagnetism: Principles and Applications in Geology, Geophysics and Archaeology. New York: Chapman and Hall. https://doi.org/10.1007/978-94-009-5955-2

Ubilla, M., \& Martínez, S. (2016). Geology and Paleontology of the Quaternary of Uruguay. New York: Springer. https://doi.org/10.1007/978-3-319-29303-5

Viana Sibeli, A., \& Borges, C. T. (2014). Compreendendo ferramentas líticas a partir das persistências e das variabilidades técnicas. Estudo de caso dos sítios GO-CP-17 e 
MT-SL-31, Região Centro Oeste do Brasil. In M. Farias, \& A. Lourdeau (Eds.), Peuplement et Modalités d'Occupation de l'Amérique du Sud: L'Apport de la Technologie Lithique (pp. 65-95). Prigonrieux: @rchéo-éditions.com.

Weitzel, C., Flegenheimer, N., Colombo, M., \& Martínez, J. (2014). Breakage Patterns on Fishtail Projectile Points: Experimental and Archaeological Cases. Ethnoarchaeology: Journal of Archaeological, Ethnographic and Experimental Studies, 6, 81-102. https://doi.org/10.1179/1944289014Z.00000000017

White, P. (1968). Ston Naip Bilong Tumbuna: The Living Stone Age in New Guinea. In F. Bordes, \& D. de Sonneville Bordes (Eds.), La Préhistoire: Problemes et tendances (pp. 511-516). Paris: Editions du CNRS. 